\title{
Acetylation of the catalytic lysine inhibits kinase activity in PI3Kס
}

Julie C. L. Fournier ${ }^{\dagger, \sharp}$, John P. Evans ${ }^{z}$, Francesca Zappacosta§, Daniel A. Thomas ${ }^{z}$, Vipulkumar K. Patel ${ }^{\dagger}, *$, Gemma V. White ${ }^{\dagger}$, Sebastien Campos ${ }^{\|}$, Nicholas C. O. Tomkinson

†SK Medicines Research Centre, Gunnels Wood Road, Stevenage, Hertfordshire SG1 2NY, UK

Department of Pure and Applied Chemistry, WestCHEM, University of Strathclyde, 295 Cathedral Street, Glasgow G1 1XL, UK

${ }^{z}$ Arctoris, 120E Olympic Avenue, Milton Park, Oxford, OX14 4SA

$\S$ GSK, South Collegeville Road, Collegeville, PA 19426, USA

"Pharmaron, West Hill Innovation Park, Hertford Road, Hoddesdon, Hertfordshire EN11 9FH, UK

\section{Author contact information:}

Julie C. L. Fournier - julie.8.fournier@gsk.com ; julie.fournier@strath.ac.uk

John P. Evans - john.evans@arctoris.com

Francesca Zappacosta - francesca.zappacosta@gsk.com

Daniel A. Thomas - daniel.thomas@arctoris.com

Vipulkumar K. Patel - vipul.k.patel@gsk.com

Gemma V. White-gemma.v.white@gsk.com

Sebastien Campos - sebastien.campos@pharmaron-uk.com

Nicholas C. O. Tomkinson - nicholas.tomkinson@strath.ac.uk 


\section{Table of Contents}

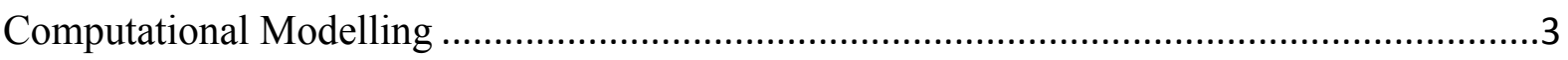

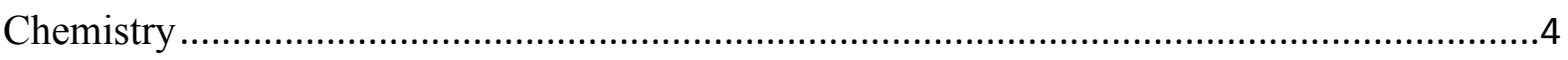

Recombinant protein production................................................................................19

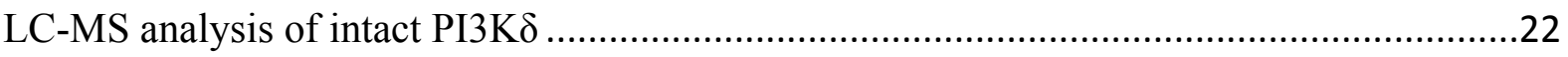

Identification of modification site(s) by LC-MS/MS .........................................................25

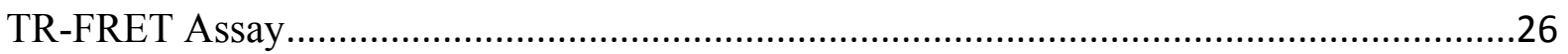

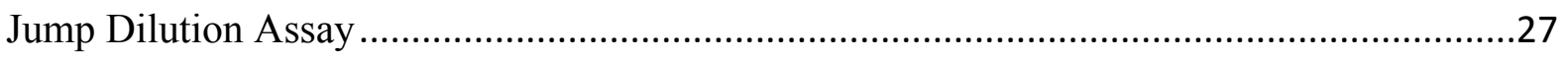

Chemoproteomic kinobead binding assay ......................................................................

Supplementary References ........................................................................................ 


\section{Computational Modelling}

Structures presented in Figure 2 were modelled using Molecular Operating Environment (MOE) 2019 (2019.0101 release).

\section{Compound 3}

Modelling of compound $\mathbf{3}$ in the PI $3 \mathrm{~K} \delta$ active site was achieved from the crystal structure of a closely related compound (3VOIH: private structure, not deposited in PDB). The starting crystal structure was prepared for simulation using the inbuilt structure preparation tool to balance charges, cap free protein residues and simulate proton locations throughout the structure. An initial energy minimization of the system was performed at this stage, using the Amber10:EHT force field, and applying the following constraints:

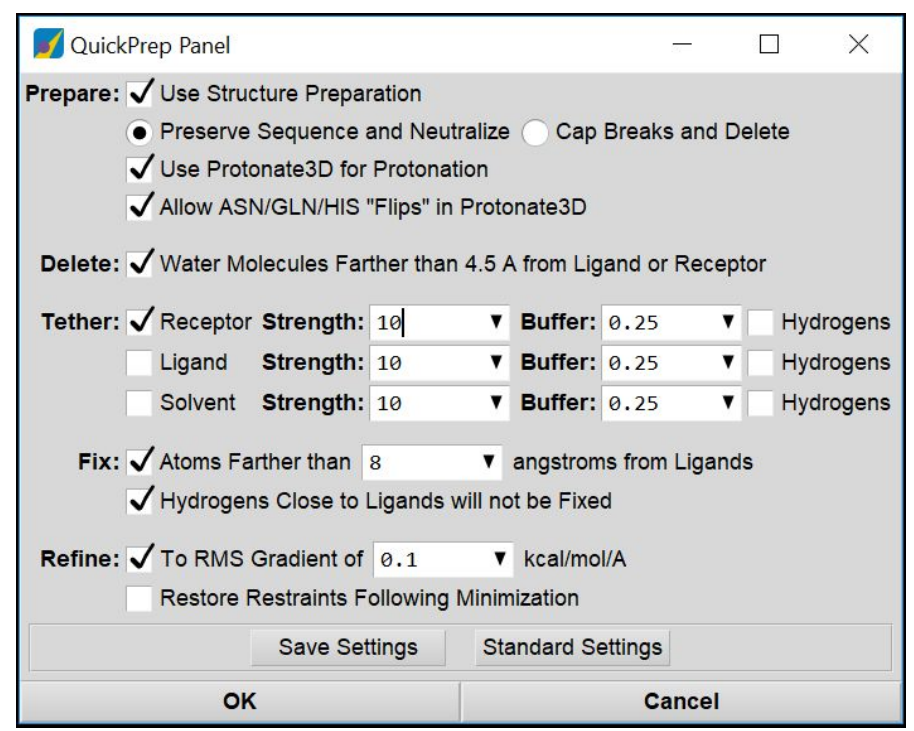

Figure S1 - Screenshot of the QuickPrep panel settings used to prepare structures in MOE

\section{Compound 4 and 5}

Known crystal structure for compound 4 (PDB accession code: 6TNR) ${ }^{l}$ was prepared for simulation as described previously.

The ligand was then modified using the MOE Builder tool to represent compound 5. After the desired modifications were carried out, an energy minimization was performed.

For each of the 3 ligands, structures were investigated qualitatively after minimization for any abnormal bond angles or bond lengths. 


\section{Chemistry}

\section{General methods}

All reagents were used as received from commercial sources (Sigma Aldrich, Alfa Aesar, Apollo Scientific etc.), unless otherwise stated. Commercially available HPLC grade solvents were used for all syntheses, work-up and isolation procedures, unless otherwise stated. Automated column chromatography was conducted on a Teledyne Isco Combiflash Rf system using RediSep Rf Silica cartridges (for normal phase), or Biotage KP-C18-HS cartridges (for reverse phase). Elution utilized standard HPLC grade solvents provided by Sigma Aldrich, with the desired modifier (for reverse phase) added in-house, unless otherwise stated.

Liquid Chromatography Mass Spectrometry (LC-MS) used for reaction monitoring, and final purity analysis. Mass Directed Automated Preparative HPLC (MDAP) purifications were conducted on a Waters FractionLynx system comprising of a Waters 600 pump with extended pump heads, Waters 2700 autosampler, Waters 996 diode array and Gilson 202 fraction collector. The high performance liquid chromatography (HPLC) separation was conducted on a Xselect C18 column ( $150 \mathrm{~mm} \times 30 \mathrm{~mm}$ internal diameter, $5 \mu \mathrm{m}$ packing diameter) at ambient temperature, utilizing an appropriate elution gradient of water $(0.1 \% v / v$ formic acid) and acetonitrile $(0.1 \% v / v$ formic acid $)$ as determined by analytical LC-MS. The software used was MassLynx 3.5 with FractionLynx 4.1. Due to the formic acid solvent modifier, basic compounds isolated by MDAP were expected to form partial formate salts, however these were not fully characterised.

NMR spectra were recorded using a Bruker AV-400 $\left({ }^{1} \mathrm{H}=400 \mathrm{MHz},{ }^{13} \mathrm{C}=101 \mathrm{MHz}\right)$. Chemical shifts $(\delta)$ are reported in parts per million $(\mathrm{ppm})$ relative to solvent $\left(\mathrm{CDCl}_{3}{ }^{1} \mathrm{H}=7.27\right.$ ppm, $\left.{ }^{13} \mathrm{C}=77.0 \mathrm{ppm} ;\left(\mathrm{CD}_{3}\right)_{2} \mathrm{SO}{ }^{1} \mathrm{H}=2.50 \mathrm{ppm},{ }^{13} \mathrm{C}=39.5 \mathrm{ppm}\right)$ and coupling constants $(J)$ in Hz. The following abbreviations are used for multiplicities: $\mathrm{s}=$ singlet; br. $\mathrm{s}=$ broad singlet; $\mathrm{d}$ $=$ doublet; $\mathrm{t}=$ triplet; $\mathrm{q}=$ quartet; $\mathrm{m}=$ multiplet; $\mathrm{dd}=$ doublet of doublets; $\mathrm{dt}=$ doublet of triplets; spt $=$ septet. If not specifically stated, the NMR experiments were run at $30{ }^{\circ} \mathrm{C}$.

High Resolution Mass Spectrometry (HRMS) spectra were recorded on a Waters XEVO G2XS quadrupole time-of flight mass spectrometer using positive electrospray ionization, with analytes separated on an Acquity UPLC CSH C18 column $(100 \mathrm{~mm}$ x $2.1 \mathrm{~mm}, 1.7 \mu \mathrm{m}$ packing diameter). LC conditions were $0.8 \mathrm{~mL} \cdot \mathrm{min}^{-1}$ flow rate, $50{ }^{\circ} \mathrm{C}$, injection volume $0.2 \mu \mathrm{L}$. Gradient elution with (A) water containing $0.1 \%(v / v)$ formic acid and (B) acetonitrile containing $0.1 \%(v / v)$ formic acid. Gradient conditions were initially $5 \% \mathrm{~B}$, increasing linearly 
to $93 \% \mathrm{~B}$ over $8.5 \mathrm{~min}$, remaining at $93 \% \mathrm{~B}$ for $0.5 \mathrm{~min}$ then decreasing linearly to $5 \% \mathrm{~B}$ over $0.5 \mathrm{~min}$ followed by an equilibration period of $0.5 \mathrm{~min}$ prior to the next injection. Mass to charge ratios $(\mathrm{m} / \mathrm{z})$ are reported in Da.

Infrared spectra were recorded using a Perkin Elmer Spectrum One spectrometer. Absorption frequencies $\left(v_{\max }\right)$ are reported in wavenumbers $\left(\mathrm{cm}^{-1}\right)$.

Melting Point (MP) measured on a Stuart SMP40 MP apparatus.

\section{LC-MS method:}

The Liquid Chromatography (LC) analysis was conducted on an Acquity UPLC CSH C18 column (50 mm x $2.1 \mathrm{~mm}$ internal diameter, $1.7 \mu \mathrm{m}$ packing diameter) at $40{ }^{\circ} \mathrm{C}$ using a $0.5 \mu \mathrm{L}$ injection volume.

The solvents employed were:

$\mathrm{A}=0.1 \% v / v$ solution of formic acid in water.

$\mathrm{B}=0.1 \% v / v$ solution of formic acid in acetonitrile.

The gradient employed was:

Time (min) Flow Rate (mL/min) $\quad \%$ A $\quad \%$ B

\begin{tabular}{llll}
\hline $\mathbf{0 . 0 0}$ & 1 & 97 & 3 \\
$\mathbf{1 . 5 0}$ & 1 & 5 & 95 \\
$\mathbf{1 . 9 0}$ & 1 & 5 & 95 \\
$\mathbf{2 . 0 0}$ & 1 & 97 & 3
\end{tabular}

The UV detection was a summed signal from wavelength of $210 \mathrm{~nm}$ to $350 \mathrm{~nm}$. Mass spectra were recorded on a Waters ZQ mass spectrometer using alternate-scan positive and negative electrospray ionization ( $\mathrm{ES}^{+}$and $\left.\mathrm{ES}^{-}\right)$with a scan range of 100 to $1000 \mathrm{amu}$, scan time of 0.27 $\mathrm{s}$ and an inter-scan delay of $0.10 \mathrm{~s}$.

\section{$\underline{\text { Synthetic route to advanced brominated intermediate } \mathbf{8}}$}

The synthetic route to 2-(1-(2-((6-bromo-1,3-dihydroisobenzofuran-4-yl)oxy)ethyl)piperidin4-yl)propan-2-ol 8 is shown is Scheme S1, as described by Henley et al. in previous PI3K $\delta$ work. $^{1}$ 


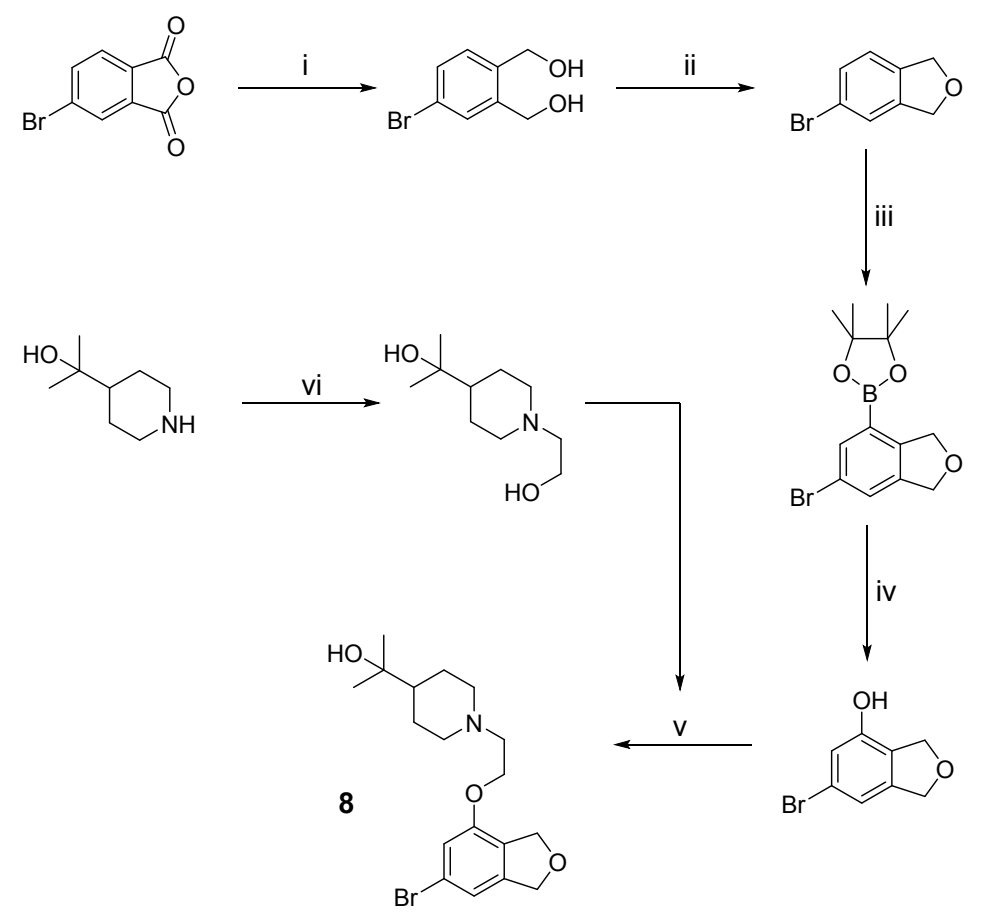

Scheme S1 - Synthesis of 2-(1-(2-((6-bromo-1,3-dihydroisobenzofuran-4yl)oxy)ethyl)piperidin-4-yl)propan-2-ol 8; reagents and conditions: i) $\mathrm{BH}_{3} \cdot \mathrm{THF}$, THF, r.t., $94 \%$; ii) $\mathrm{MnO}_{2}, \mathrm{DCM}, 40{ }^{\circ} \mathrm{C}$, then triethylsilane, TFA, $40{ }^{\circ} \mathrm{C}, 55 \%$; iii) $\mathrm{B}_{2} \mathrm{pin}_{2}$, $[\operatorname{Ir}(\mathrm{COD}) \mathrm{OMe}]_{2}$, ditBuBiPy, THF, reflux; iv) Oxone, acetone/water, r.t., 58\% (2 steps); v) 2(1-(2-hydroxyethyl)piperidin-4-yl)propan-2-ol, DIAD, $\mathrm{PPh}_{3}, \quad \mathrm{THF}, \quad$ r.t., 86\%; vi) 2bromoethanol, $\mathrm{K}_{2} \mathrm{CO}_{3}$, acetonitrile, $75^{\circ} \mathrm{C}$, quant. yield

$\underline{\text { 5-(7-(2-(4-(2-Hydroxypropan-2-yl)piperidin-1-yl)ethoxy)-1,3-dihydroisobenzofuran-5-yl)-2- }}$ methoxypyridin-3-ol 9

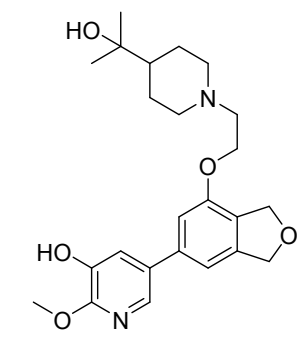

In a round-bottom flask were added 2-(1-(2-((6-bromo-1,3-dihydroisobenzofuran-4yl)oxy)ethyl)piperidin-4-yl)propan-2-ol hydrochloride $8 \quad(1.997 \quad \mathrm{~g}, \quad 4.75 \mathrm{mmol})$, bis(pinacolato)diboron $(2.339 \mathrm{~g}, 9.21 \mathrm{mmol})$, potassium acetate $(1.468 \mathrm{~g}, 14.96 \mathrm{mmol})$, and $\mathrm{PdCl}_{2}$ (dppf) (355 mg, $\left.0.49 \mathrm{mmol}\right)$ in anhydrous 1,4-dioxane $(30 \mathrm{~mL})$. The resulting solution was degassed. The mixture was stirred at $90{ }^{\circ} \mathrm{C}$ under nitrogen for $3 \mathrm{~h}$. The solvent was then evaporated in vacuo to afford a black solid. The solid was suspended in DCM and the suspension was filtered through Celite. The filtrate was concentrated in vacuo to afford a black solid. The solid was purified by automated reverse phase column chromatography (liquid loaded; $0-95 \%$ water $(+0.1 \%$ formic acid):acetonitrile $(+0.1 \%$ formic acid $))$. The appropriate 
fractions were combined and the solvent removed in vacuo to afford 2-(1-(2-((6- $(4,4,5,5-$ tetramethyl-1,3,2-dioxaborolan-2-yl)-1,3-dihydroisobenzofuran-4-yl)oxy)ethyl)piperidin-4yl)propan-2-ol as a brown oil (3.09 g). LC-MS and NMR showed the product contained a mixture of the desired boronic ester, the corresponding boronic acid and residual pinacol from boronic ester hydrolysis.

In a round-bottom flask were added 5-bromo-2-methoxypyridin-3-ol (971 mg, $4.76 \mathrm{mmol})$, previously described 2-(1-(2-((6-(4,4,5,5-tetramethyl-1,3,2-dioxaborolan-2-yl)-1,3dihydroisobenzofuran-4-yl)oxy)ethyl)piperidin-4-yl)propan-2-ol $(2.047 \mathrm{~g}, 4.75 \mathrm{mmol}$, assuming full conversion from previous reaction), sodium carbonate $(2.521 \mathrm{~g}, 23.79 \mathrm{mmol})$ and $\mathrm{PdCl}_{2}$ (dppf) $(370 \mathrm{mg}, 0.51 \mathrm{mmol})$ in 1,4-dioxane $(20 \mathrm{~mL})$ and water $(5 \mathrm{~mL})$. The reaction was stirred at $90^{\circ} \mathrm{C}$ for $6 \mathrm{~h}$. The reaction mixture was concentrated in vacuo to afford a brown solid, which was suspended in DCM and filtered through Celite. The filtrate was concentrated in vacuo to afford a brown oil. The oil was purified by automated normal phase column chromatography $\left(2-7 \% \mathrm{NH}_{3}(2 \mathrm{M}\right.$ in $\mathrm{MeOH})$ in $\left.\mathrm{DCM}\right)$. The appropriate fractions were combined and concentrated in vacuo to afford 5-(7-(2-(4-(2-hydroxypropan-2-yl)piperidin-1yl)ethoxy)-1,3-dihydroisobenzofuran-5-yl)-2-methoxypyridin-3-ol as a brown solid (1.502 g, $3.51 \mathrm{mmol}, 74 \%)$.

MP: $59-62{ }^{\circ} \mathrm{C}$ (decomp). $v_{\max }$ (neat): 3375 (br.), 2970, 2938, 2852, 1672, 1598, 1571, 1471, $1404 \mathrm{~cm}^{-1} .{ }^{1} \mathrm{H}$ NMR $\left(400 \mathrm{MHz},\left(\mathrm{CD}_{3}\right)_{2} \mathrm{SO}\right) \delta 9.56$ (br. s, 1H), 7.92 (d, J=2.2 Hz, 1H), 7.36 (d, $J=2.2 \mathrm{~Hz}, 1 \mathrm{H}), 7.10-7.06(\mathrm{~m}, 2 \mathrm{H}), 5.05-5.01(\mathrm{~m}, 2 \mathrm{H}), 4.99-4.94(\mathrm{~m}, 2 \mathrm{H}), 4.22(\mathrm{t}, J=5.6 \mathrm{~Hz}$, 2H), $4.00(\mathrm{~s}, 1 \mathrm{H}), 3.91(\mathrm{~s}, 3 \mathrm{H}), 3.03-2.95(\mathrm{~m}, 2 \mathrm{H}), 2.66(\mathrm{t}, J=5.6 \mathrm{~Hz}, 2 \mathrm{H}), 2.54(\mathrm{~s}, 5 \%$ weight DMSO contamination), 1.99-1.88 (m, 2H), 1.67-1.58 (m, 2H), 1.28-1.09 (m, 3H), 1.01 (s, $6 \mathrm{H}) .{ }^{13} \mathrm{C}$ NMR $\left(101 \mathrm{MHz},\left(\mathrm{CD}_{3}\right)_{2} \mathrm{SO}\right) \delta 153.3,153.0,141.6,141.2,139.0,133.6,130.2,125.5$, 120.4, 111.3, 109.1, 73.1, 70.9, 70.2, 66.2, 56.8, 54.3 (2C), 53.0, 46.8, 40.4 (DMSO contamination), $26.8(2 \mathrm{C}), 26.5(2 \mathrm{C})$. LC-MS: $\mathrm{t}_{\mathrm{R}}=0.51 \mathrm{~min},\left[\mathrm{M}+\mathrm{H}^{+}\right]=429.4$, (95\% purity). HRMS: $\left(\mathrm{C}_{24} \mathrm{H}_{33} \mathrm{~N}_{2} \mathrm{O}_{5}\right)\left[\mathrm{M}+\mathrm{H}^{+}\right]$requires 429.2389 , found $\left[\mathrm{M}+\mathrm{H}^{+}\right] 429.2389$.

5-(7-(2-(4-(2-hydroxypropan-2-yl)piperidin-1-yl)ethoxy)-1,3-dihydroisobenzofuran-5-yl)-2methoxypyridin-3-ol was used as described above for the subsequent synthesis of DHB esters 5,6 and 7.

Prior to biochemical testing, a sample of 5-(7-(2-(4-(2-hydroxypropan-2-yl)piperidin-1yl)ethoxy)-1,3-dihydroisobenzofuran-5-yl)-2-methoxypyridin-3-ol (100 mg, $0.23 \mathrm{mmol}$ ) was purified by MDAP to remove the brown staining. The appropriate fractions were combined and concentrated under a stream of nitrogen to give a clear gum. The gum was dissolved in 
acetonitrile and freeze-dried to afford the title compound as a white solid (46 $\mathrm{mg}, 0.10 \mathrm{mmol}$ ), as a putative formate salt.

${ }^{1} \mathrm{H}$ NMR (400 MHz, $\left.\left(\mathrm{CD}_{3}\right)_{2} \mathrm{SO}\right) \delta 8.23$ (s, 1.2 equivalents of residual formate), 7.92 (d, $J=2.1$ $\mathrm{Hz}, 1 \mathrm{H}), 7.37$ (d, $J=2.1 \mathrm{~Hz}, 1 \mathrm{H}), 7.10-7.06$ (m, 2H), 5.05-5.01 (m, 2H), 4.99-4.94 (m, 2H), $4.22(\mathrm{t}, J=5.9 \mathrm{~Hz}, 2 \mathrm{H}), 3.91(\mathrm{~s}, 3 \mathrm{H}), 3.03-2.96(\mathrm{~m}, 2 \mathrm{H}), 2.67(\mathrm{t}, J=5.9 \mathrm{~Hz}, 2 \mathrm{H}), 2.00-1.91$ $(\mathrm{m}, 2 \mathrm{H}), 1.67-1.59(\mathrm{~m}, 2 \mathrm{H}), 1.29-1.09(\mathrm{~m}, 3 \mathrm{H}), 1.01(\mathrm{~s}, 6 \mathrm{H})$ (tertiary alcohol and phenol protons not observed). LC-MS: $\mathrm{t}_{\mathrm{R}}=0.51 \mathrm{~min},\left[\mathrm{M}+\mathrm{H}^{+}\right]=429.3,(95 \%$ purity).

5-(7-(2-(4-(2-Hydroxypropan-2-yl)piperidin-1-yl)ethoxy)-1,3-dihydroisobenzofuran-5-yl)-2methoxypyridin-3-yl acetate 5

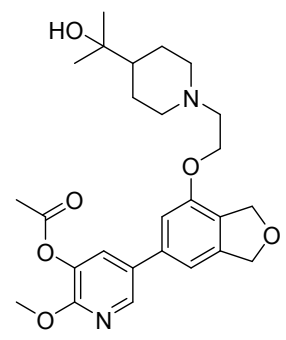

To a solution of 5-(7-(2-(4-(2-hydroxypropan-2-yl)piperidin-1-yl)ethoxy)-1,3dihydroisobenzofuran-5-yl)-2-methoxypyridin-3-ol (74 $\mathrm{mg}, 0.17 \mathrm{mmol})$ and triethylamine $(0.04 \mathrm{~mL}, 0.29 \mathrm{mmol})$ stirring in anhydrous DCM $(2 \mathrm{~mL})$ was added acetic anhydride $(0.02 \mathrm{~mL}, 0.21 \mathrm{mmol})$. The reaction was stirred at r.t. under nitrogen for $16 \mathrm{~h}$. LC-MS showed poor conversion to product: triethylamine $(0.08 \mathrm{~mL}, 0.57 \mathrm{mmol})$ and acetic anhydride $(0.04$ $\mathrm{mL}, 0.42 \mathrm{mmol}$ ) were added to the reaction, which was stirred at r.t. under nitrogen for $16 \mathrm{~h}$. The mixture was concentrated under nitrogen and purified by MDAP. The appropriate fractions were combined and concentrated under a stream of nitrogen to give a clear gum. The gum was dissolved in acetonitrile and freeze-dried to afford a brown solid; insufficient purity. The solid was purified a second time by MDAP. The appropriate fractions were combined and freezedried to afford the title compound as a white solid (27 mg, $0.05 \mathrm{mmol}, 29 \%)$, as a putative formate salt.

MP: $77-82{ }^{\circ}$ C. $v_{\max }$ (neat): 3416 (br.), 2939, 2854, 1774, 1597, 1476, $1394 \mathrm{~cm}^{-1} .{ }^{1} \mathrm{H}$ NMR (400 $\left.\mathrm{MHz},\left(\mathrm{CD}_{3}\right)_{2} \mathrm{SO}\right) \delta 8.42(\mathrm{~d}, J=2.2 \mathrm{~Hz}, 1 \mathrm{H}), 8.17$ (s, 1.2 equivalents of residual formate), 7.95 $(\mathrm{d}, J=2.2 \mathrm{~Hz}, 1 \mathrm{H}), 7.22-7.15(\mathrm{~m}, 2 \mathrm{H}), 5.07-5.01(\mathrm{~m}, 2 \mathrm{H}), 5.00-4.94(\mathrm{~m}, 2 \mathrm{H}), 4.25(\mathrm{t}, J=6.0$ Hz, 2H), 3.92 (s, 3H), 3.08-2.99 (m, 2H), 2.73 (t, $J=6.0$ Hz, 2H), 2.31 (s, 3H), 2.06-1.98 (m, $2 \mathrm{H}), 1.69-1.61(\mathrm{~m}, 2 \mathrm{H}), 1.30-1.11(\mathrm{~m}, 3 \mathrm{H}), 1.02(\mathrm{~s}, 6 \mathrm{H})$ (tertiary alcohol proton not observed). ${ }^{13} \mathrm{C}$ NMR (101 MHz, $\left.\left(\mathrm{CD}_{3}\right)_{2} \mathrm{SO}\right) \delta 168.3,163.2$ (residual formate), 155.2, 153.3, 141.8, 141.3, 137.6, 134.2, 130.1, 129.8, 126.0, 111.4, 109.2, 73.1, 70.9, 70.1, 66.0, 56.7, 54.2 (2C), 53.6, 
46.6, 26.8 (2C), $26.3(2 \mathrm{C}), 20.3$. LC-MS: $\mathrm{t}_{\mathrm{R}}=0.64 \mathrm{~min},\left[\mathrm{M}+\mathrm{H}^{+}\right]=471.3$, (95\% purity). HRMS: $\left(\mathrm{C}_{26} \mathrm{H}_{35} \mathrm{~N}_{2} \mathrm{O}_{6}\right)\left[\mathrm{M}+\mathrm{H}^{+}\right]$requires 471.2495, found $\left[\mathrm{M}+\mathrm{H}^{+}\right]$471.2495.

5-(7-(2-(4-(2-Hydroxypropan-2-yl)piperidin-1-yl)ethoxy)-1,3-dihydroisobenzofuran-5-yl)-2methoxypyridin-3-yl isobutyrate 6

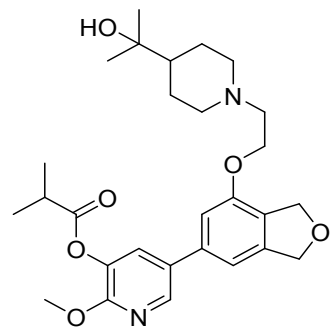

To a solution of 5-(7-(2-(4-(2-hydroxypropan-2-yl)piperidin-1-yl)ethoxy)-1,3dihydroisobenzofuran-5-yl)-2-methoxypyridin-3-ol (132 mg, $0.31 \mathrm{mmol})$, triethylamine (0.09 $\mathrm{mL}, 0.65 \mathrm{mmol})$ and $\mathrm{N}, \mathrm{N}$-dimethylpyridin-4-amine $(4 \mathrm{mg}, 0.03 \mathrm{mmol})$ stirring in anhydrous DCM $(2 \mathrm{~mL})$ was added isobutyryl chloride $(0.04 \mathrm{~mL}, 0.38 \mathrm{mmol})$. The resulting mixture was stirred at r.t. for $30 \mathrm{~min}$. The reaction mixture was then was partitioned between DCM and water. The aqueous layer was extracted with DCM. The combined organic layers were concentrated in vacuo to afford a brown gum. The gum was purified by MDAP. The appropriate fractions were combined and freeze-dried to afford the title compound as a white solid (49 mg, $0.09 \mathrm{mmol}, 29 \%$ ), as a putative partial formate salt.

MP: $48-51^{\circ}$ C. $v_{\max }$ (neat): 3402 (br.), 2970, 2941, 2855, 2797, 2700, 1761, 1596, 1505, 1472, $1425,1394 \mathrm{~cm}^{-1} .{ }^{1} \mathrm{H}$ NMR (400 MHz, $\left.\mathrm{CDCl}_{3}\right) \delta 8.44$ (s, 0.4 equivalents of residual formate), $8.20(\mathrm{~d}, J=2.1 \mathrm{~Hz}, 1 \mathrm{H}), 7.50$ (d, $J=2.1 \mathrm{~Hz}, 1 \mathrm{H}), 6.97$ (br. s, 1H), 6.85 (br. s, 1H), 5.15-5.12 (m, 2H), 5.12-5.09 (m, 2H), $4.29(\mathrm{t}, J=5.7 \mathrm{~Hz}, 2 \mathrm{H}), 3.99(\mathrm{~s}, 3 \mathrm{H}), 3.31-3.24(\mathrm{~m}, 2 \mathrm{H}), 3.00(\mathrm{t}$, $J=5.7 \mathrm{~Hz}, 2 \mathrm{H}), 2.86$ (spt, $J=6.9 \mathrm{~Hz}, 1 \mathrm{H}), 2.35-2.25$ (m, 2H), 1.84-1.75 (m, 2H), 1.62-1.49 $(\mathrm{m}, 2 \mathrm{H}), 1.40-1.36(\mathrm{~m}, 1 \mathrm{H}), 1.35(\mathrm{~d}, J=6.9 \mathrm{~Hz}, 6 \mathrm{H}), 1.18(\mathrm{~s}, 6 \mathrm{H})$ (tertiary alcohol proton not observed). ${ }^{13} \mathrm{C}$ NMR (101 MHz, $\left.\mathrm{CDCl}_{3}\right) \delta 175.0,156.0,153.4,142.3,141.6,139.1,135.1$, $130.9,129.7,126.7,112.4,109.2,74.1,72.3,72.1,65.6,56.6,54.3$ (2C), 54.1, 46.6, 34.1, 27.1 (2C), 26.0 (2C), 19.1 (2C). LC-MS: $t_{R}=0.74 \mathrm{~min},\left[\mathrm{M}+\mathrm{H}^{+}\right]=499.5$, (95\% purity). HRMS: $\left(\mathrm{C}_{28} \mathrm{H}_{37} \mathrm{~N}_{2} \mathrm{O}_{6}\right)\left[\mathrm{M}-\mathrm{H}^{+}\right]$requires 497.2652, found [M-H $\left.\mathrm{H}^{+}\right]$497.2651. 
5-(7-(2-(4-(2-Hydroxypropan-2-yl)piperidin-1-yl)ethoxy)-1,3-dihydroisobenzofuran-5-yl)-2methoxypyridin-3-yl tetrahydro-2H-thiopyran-4-carboxylate 7

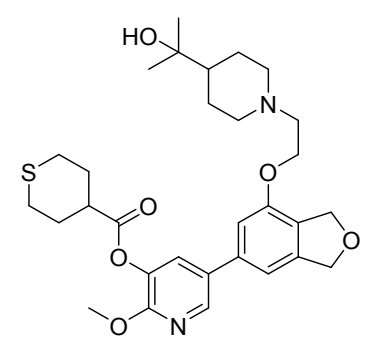

A solution of 5-(7-(2-(4-(2-hydroxypropan-2-yl)piperidin-1-yl)ethoxy)-1,3dihydroisobenzofuran-5-yl)-2-methoxypyridin-3-ol (128 mg, $0.30 \mathrm{mmol})$, tetrahydro-2Hthiopyran-4-carboxylic acid (44 $\mathrm{mg}, 0.30 \mathrm{mmol})$ and N,N-dimethylpyridin-4-amine (15 mg, $0.12 \mathrm{mmol})$ in anhydrous DCM $(3 \mathrm{~mL})$ was cooled down to $0{ }^{\circ} \mathrm{C}$ before addition of $\mathrm{N}, \mathrm{N}^{\prime}-$ dicyclohexylcarbodiimide $(123 \mathrm{mg}, 0.60 \mathrm{mmol})$. The reaction was stirred under nitrogen at 0 ${ }^{\circ} \mathrm{C}$ for $1 \mathrm{~h}$, before removing the ice bath and letting the mixture warm up to r.t.; the reaction was stirred at r.t. for $16 \mathrm{~h}$. LC-MS showed incomplete conversion. To the mixture was added tetrahydro-2H-thiopyran-4-carboxylic acid $(4 \mathrm{mg}, 0.03 \mathrm{mmol})$. The reaction was stirred at r.t. for $4 \mathrm{~h}$. Water $(1 \mathrm{~mL})$ was added to the reaction mixture and the layers were separated. The aqueous layer was extracted with DCM $(3 \times 1 \mathrm{~mL})$. The combined organic layers were concentrated in vacuo to afford a brown gum. The gum was purified by MDAP. The appropriate fractions were combined and concentrated down to $5 \mathrm{~mL}$ under a flow of nitrogen. The solution was freeze-dried to afford the title compound as a yellow solid (97 mg, $0.17 \mathrm{mmol}$, $57 \%$ ), as a putative partial formate salt.

MP: $60-64^{\circ} \mathrm{C} . v_{\max }$ (neat): 3437 (br.), 2941, 2851, 1756, 1599, 1482, $1396 \mathrm{~cm}^{-1} .{ }^{1} \mathrm{H}$ NMR (400 $\left.\mathrm{MHz}, \mathrm{CDCl}_{3}\right) \delta 8.41$ (br. s, 0.4 equivalents of residual formate), 8.23 (d, $\left.J=2.1 \mathrm{~Hz}, 1 \mathrm{H}\right), 7.50$ (d, $J=2.1 \mathrm{~Hz}, 1 \mathrm{H}), 6.99$ (br. s, 1H), 6.87 (br. s, 1H), 5.17-5.14 (m, 2H), 5.14-5.11 (m, 2H), $4.30(\mathrm{t}, J=5.5 \mathrm{~Hz}, 2 \mathrm{H}), 4.01(\mathrm{~s}, 3 \mathrm{H}), 3.33-3.24(\mathrm{~m}, 2 \mathrm{H}), 3.00(\mathrm{t}, J=5.5 \mathrm{~Hz}, 2 \mathrm{H}), 2.85-2.69$ (m, 5H), 2.46-2.35 (m, 2H), 2.35-2.24 (m, 2H), 2.16-2.03 (m, 2H), 1.87-1.76 (m, 2H), 1.63$1.48(\mathrm{~m}, 2 \mathrm{H}), 1.42-1.31(\mathrm{~m}, 1 \mathrm{H}), 1.20(\mathrm{~s}, 6 \mathrm{H}) .{ }^{13} \mathrm{C} \mathrm{NMR}\left(101 \mathrm{MHz}, \mathrm{CDCl}_{3}\right) \delta 172.4,155.6$, $153.5,142.2$, 141.7, 138.8, 134.7, 130.9, 129.5, 126.8, 112.1, 109.1, 74.0, 72.2, 72.0, 66.0, 56.8, 54.4 (2 C), 54.0, 46.8, 42.2, 29.7 (2 C), 27.4 (2 C), 27.0 (2 C), $26.3(2 \mathrm{C})$. LC-MS: $t_{\mathrm{R}}=$ $0.78 \min ,\left[\mathrm{M}+\mathrm{H}^{+}\right]=557.3$, (min. $95 \%$ purity). HRMS: $\left(\mathrm{C}_{30} \mathrm{H}_{41} \mathrm{~N}_{2} \mathrm{O}_{6} \mathrm{~S}\right)\left[\mathrm{M}+\mathrm{H}^{+}\right]$requires 557.2685, found $\left[\mathrm{M}+\mathrm{H}^{+}\right]$557.2684. 
NMR spectra:

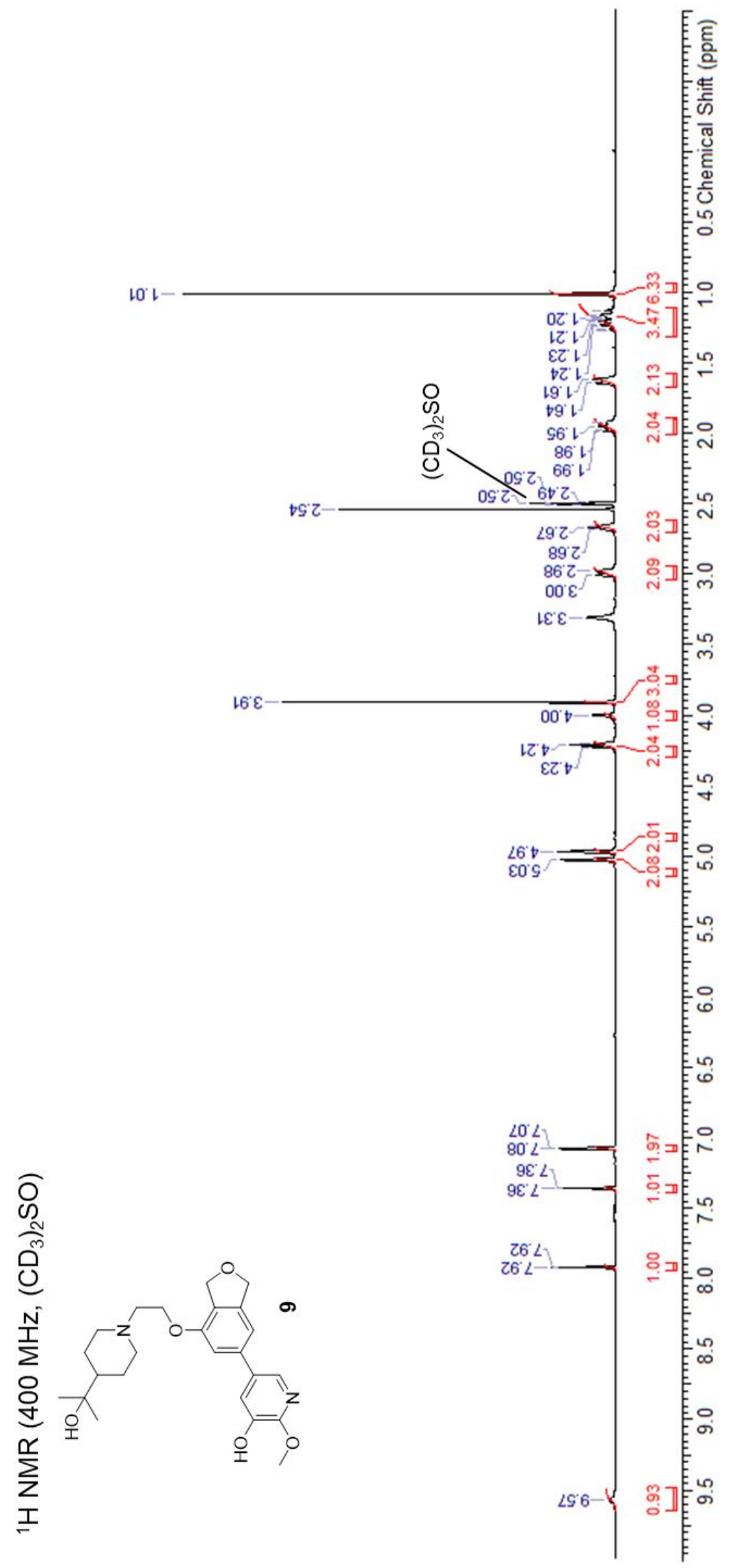




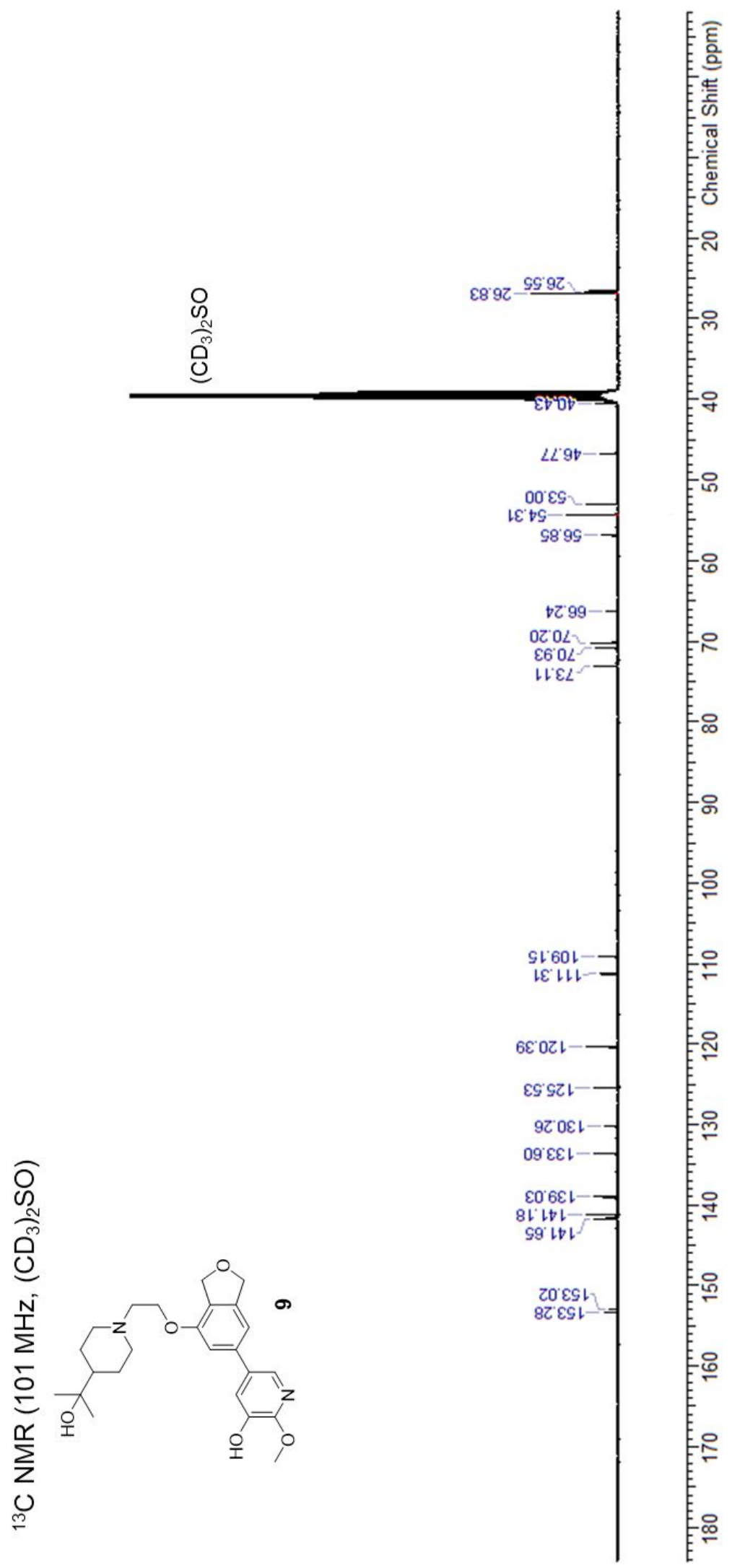




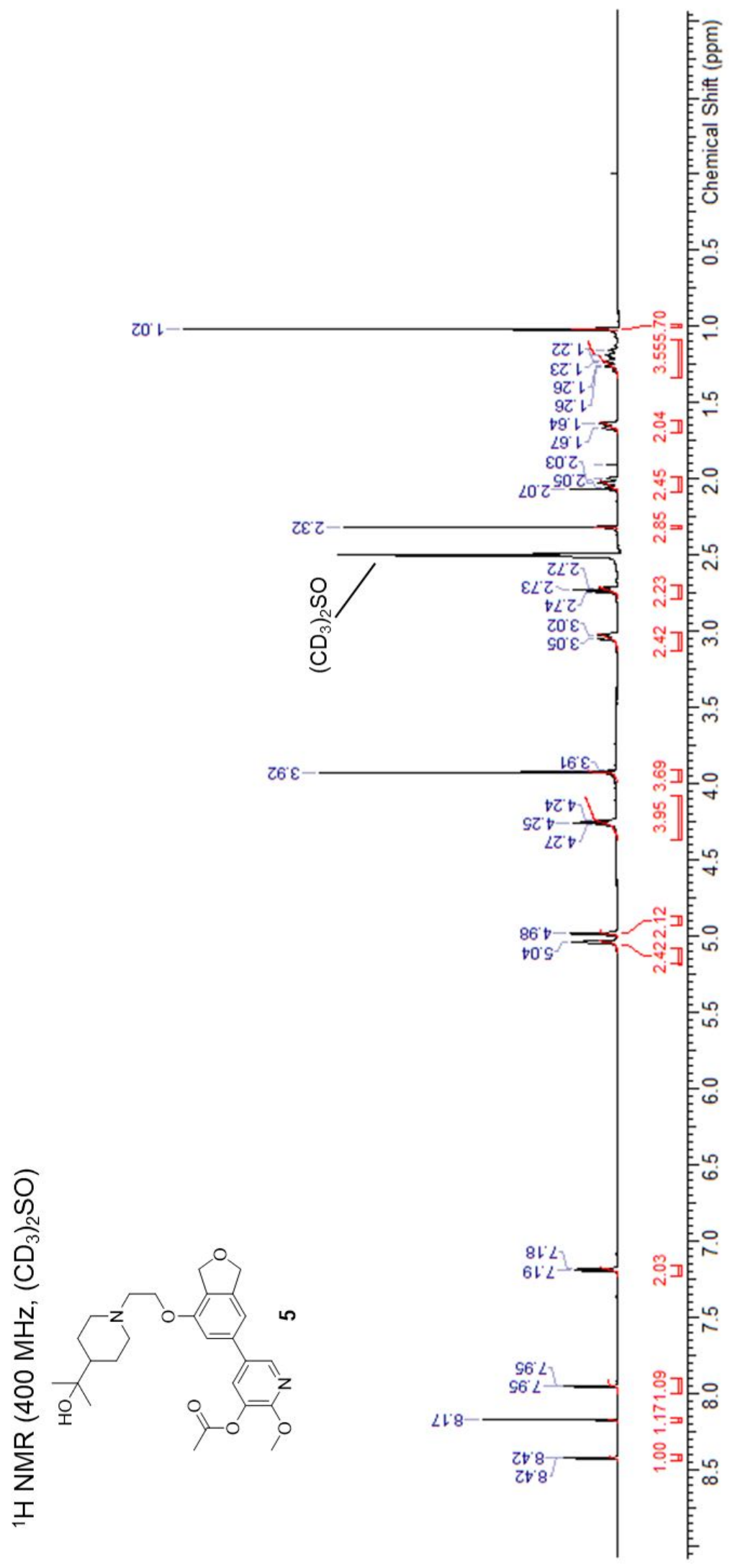




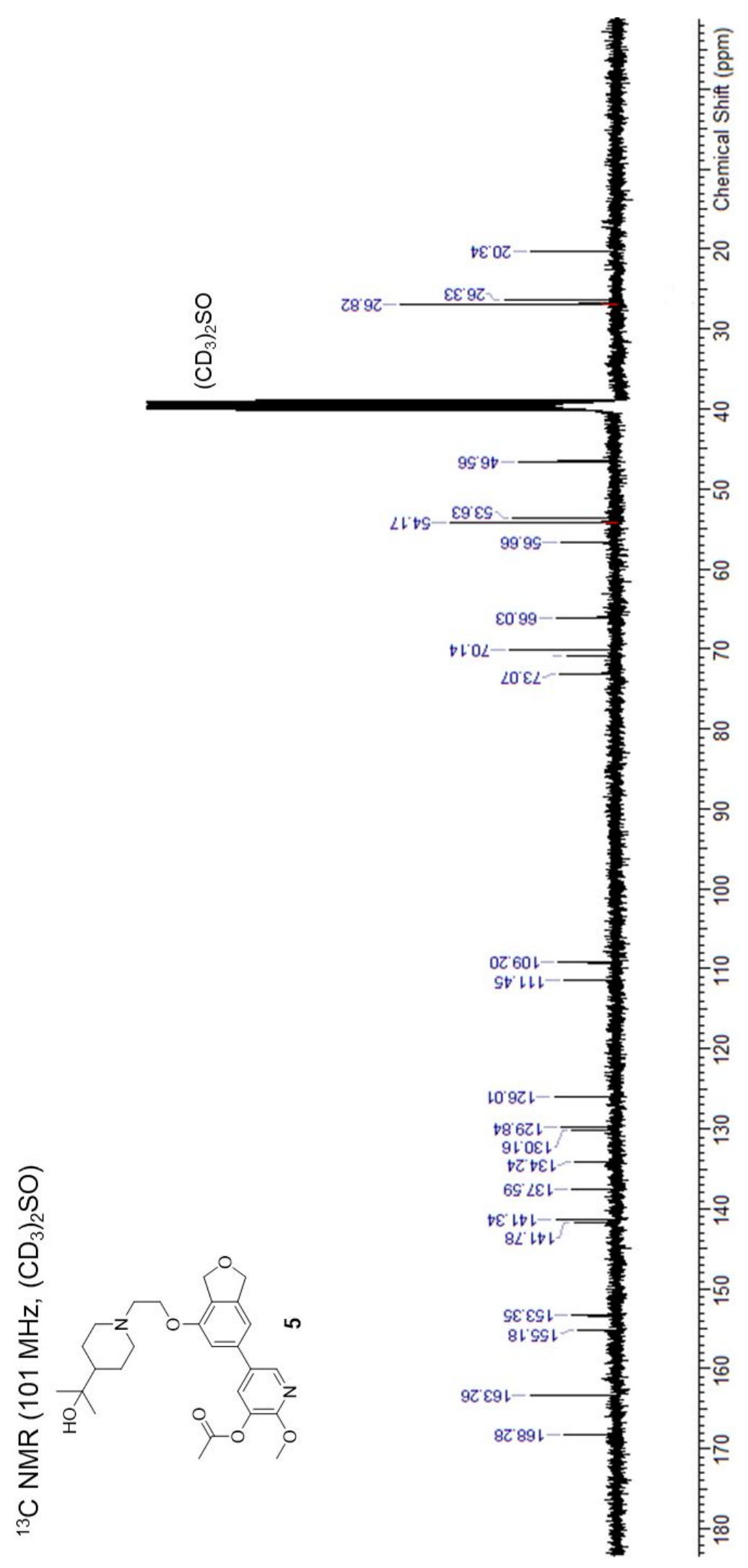




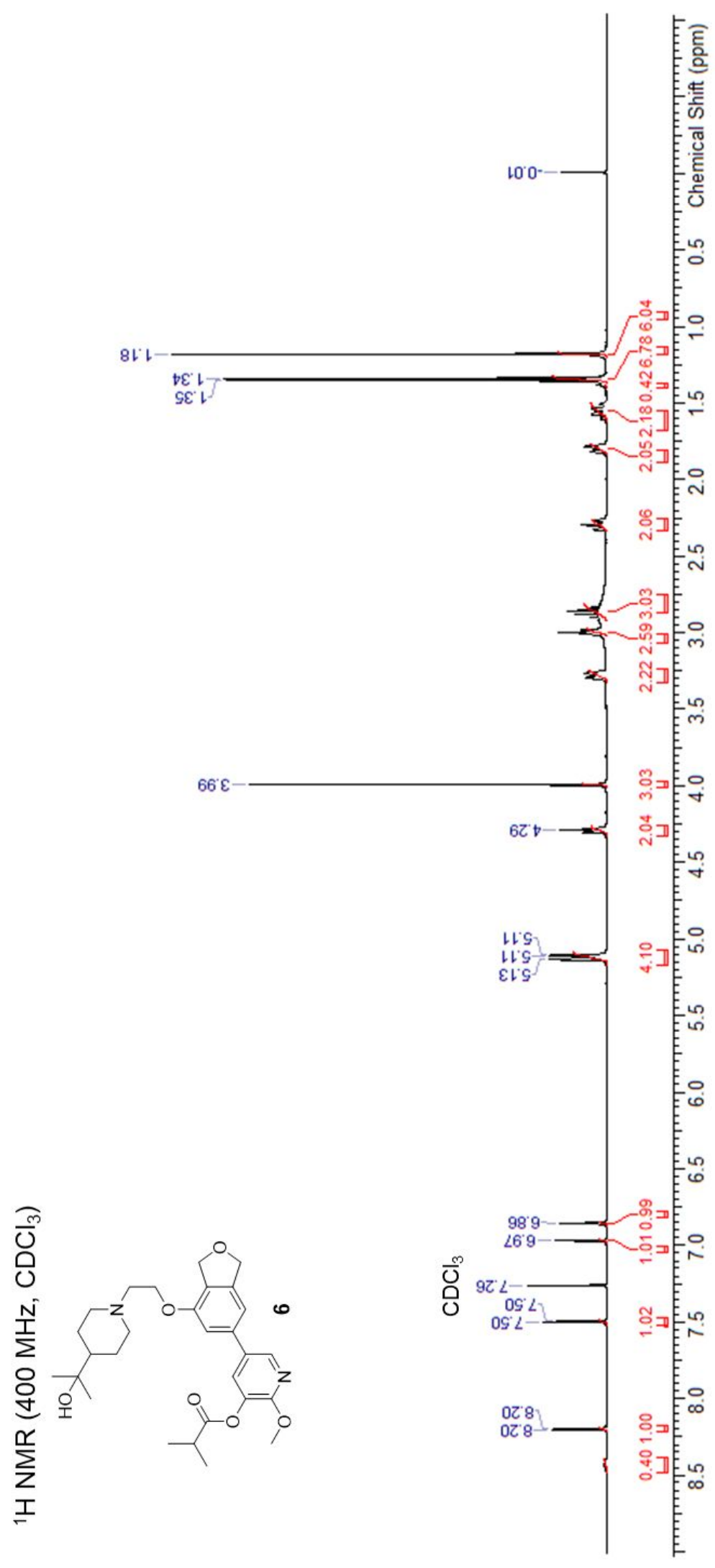




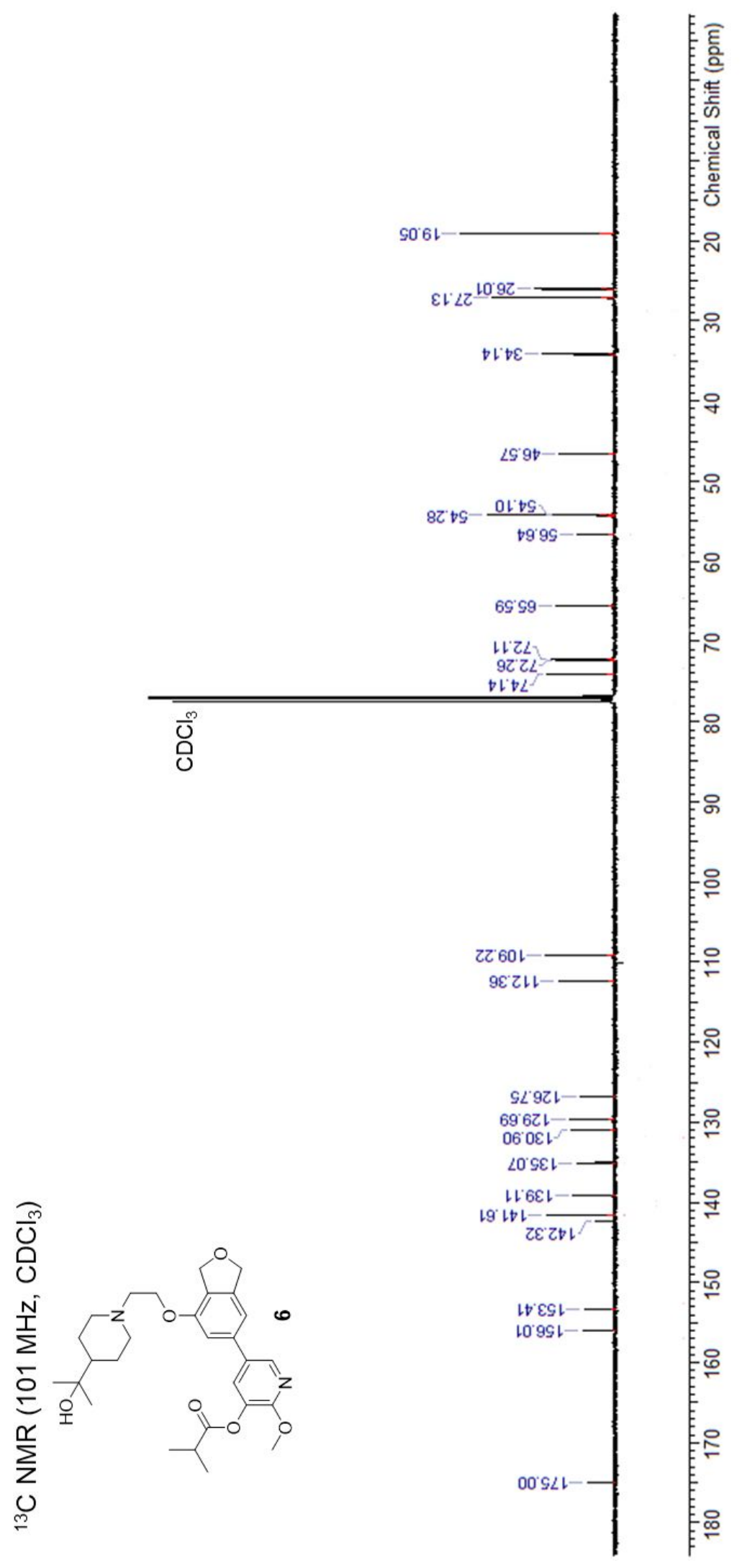




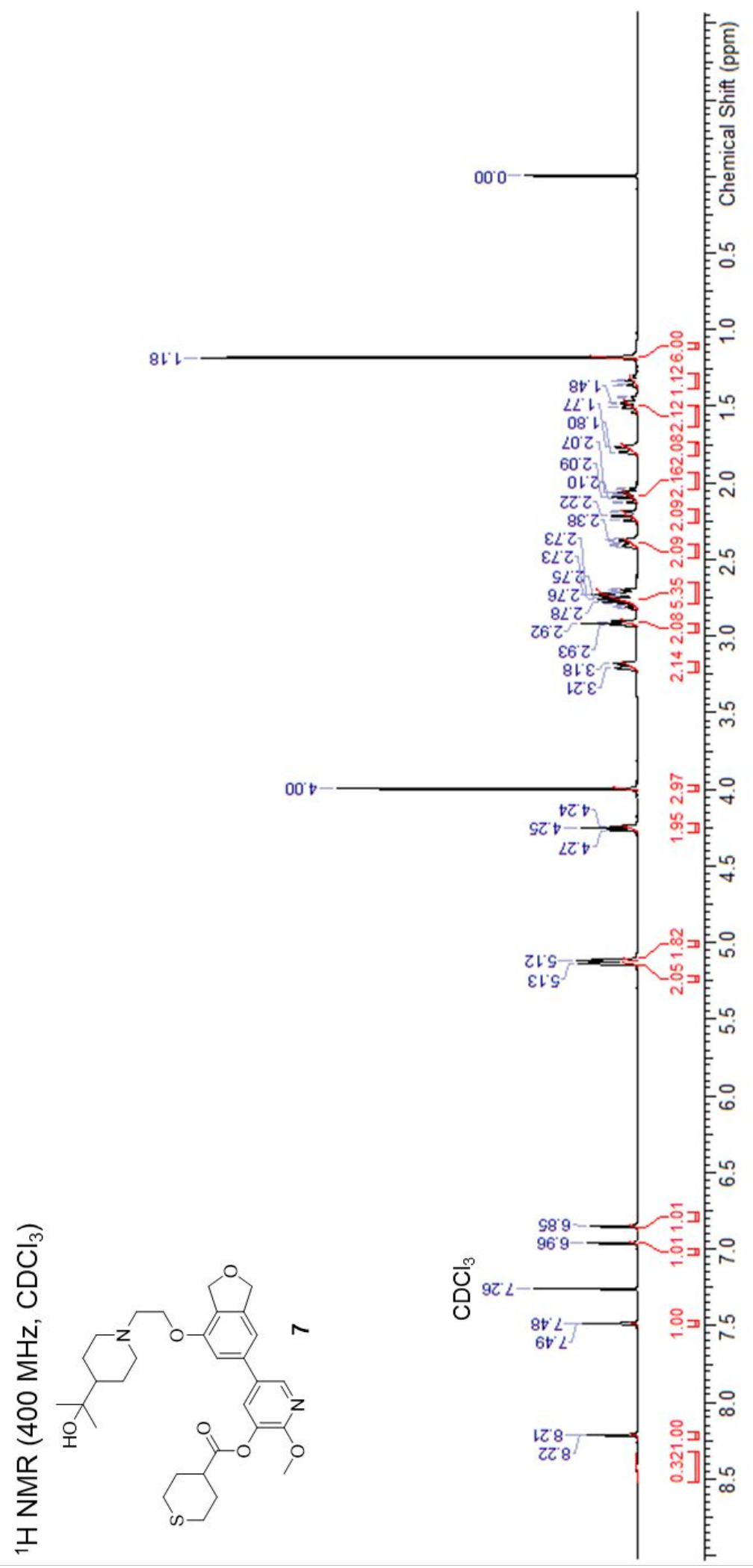




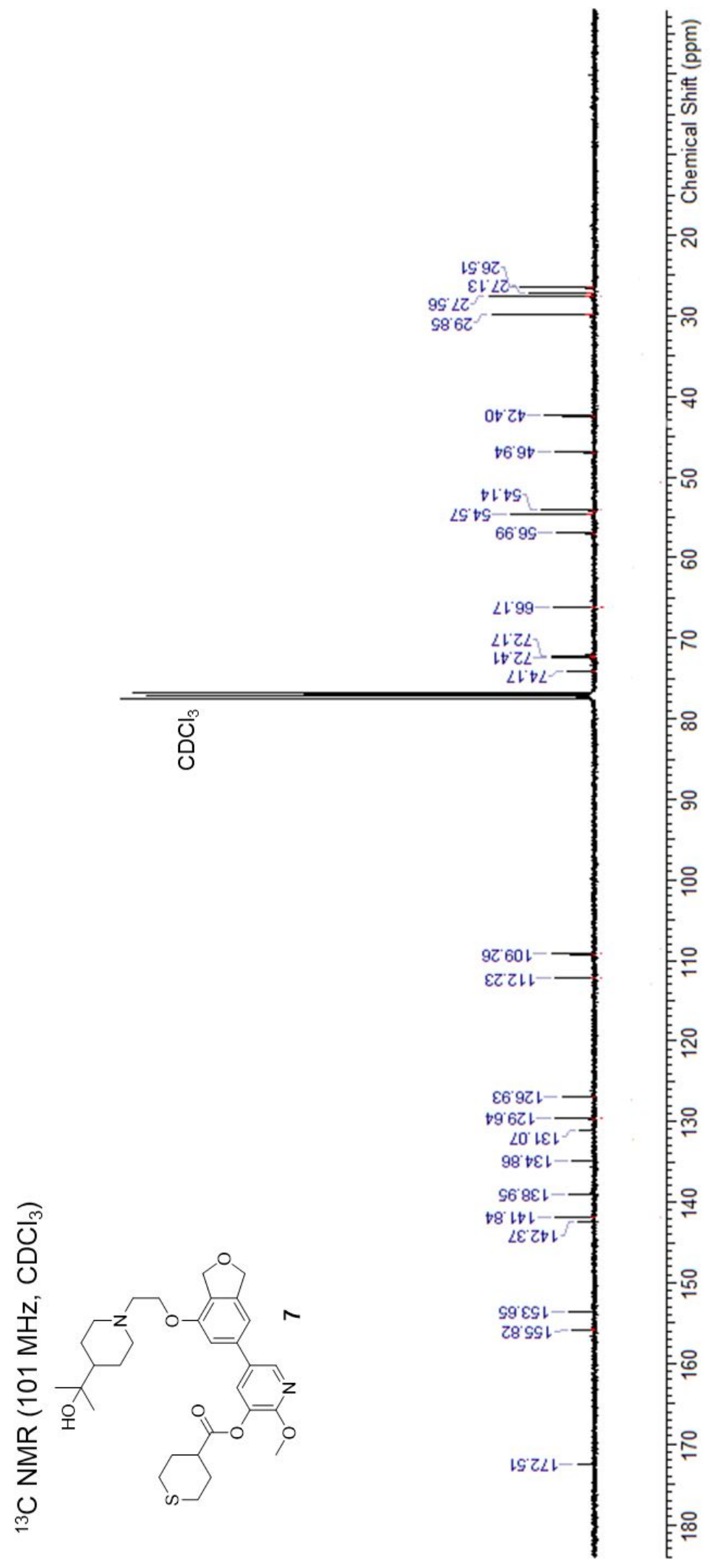




\section{Hydrolytic stability assessment}

Ester hydrolysis in DMSO (10 mM) was monitored over time by LC-MS: analysis of the chromatogram allowed to calculate the proportion of each compound present in a sample, in the presence of a fluorene internal standard. These values were plotted against time to obtain the graphs shown below. The calculations are detailed in Figure S2, using an example LC-MS trace.

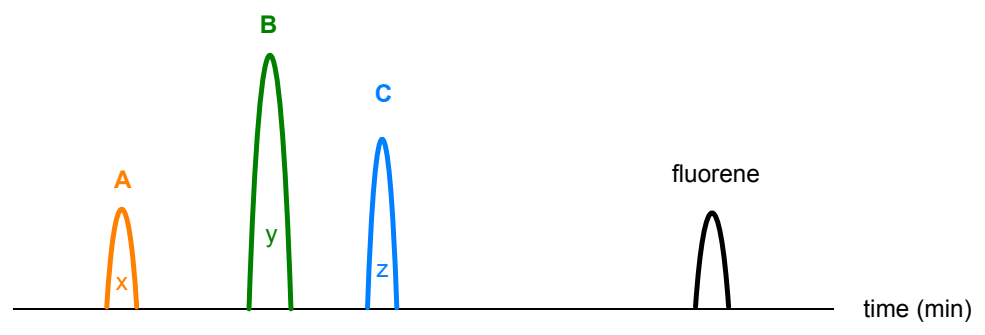

Figure S2 - LC-MS analysis. Example LC-MS trace showing a mixture of 3 compounds (A, B and $\mathrm{C}$ ) and a fluorene internal standard. The percentage peak areas calculated by the acquisition software for compounds $\mathrm{A}, \mathrm{B}$ and $\mathrm{C}$ are respectively called $\mathrm{x}, \mathrm{y}$ and $\mathrm{z}$.

The LC-MS acquisition software calculated the area under the curve for each peak detected in the trace, expressed as percentage peak area. The proportion of compound A present in the mixture $(\% \mathrm{~A})$ can be calculated from the percentage peak area values as such:

$$
\% \mathrm{~A}=x /(x+y+z)
$$

\section{Indazole ester 3}

The solution was kept at ambient temperature for 5 days and the increase of the parent phenol (10) was monitored by LC-MS. Hydrolysis to the phenol reached $15 \%$ within the first minutes, then progressed steadily to 35\% (Figure S3). Two other by-products were observed by LC-MS (Figure S3): one had the same mass as acetate $\mathbf{3}$ but a different retention time, which could correspond to formation of acetamide regioisomer 11 (supported by structural studies on related analogues, unpublished results). The mass and retention time of the second by-product were consistent with diacetylated $\mathbf{1 2}$. 
3

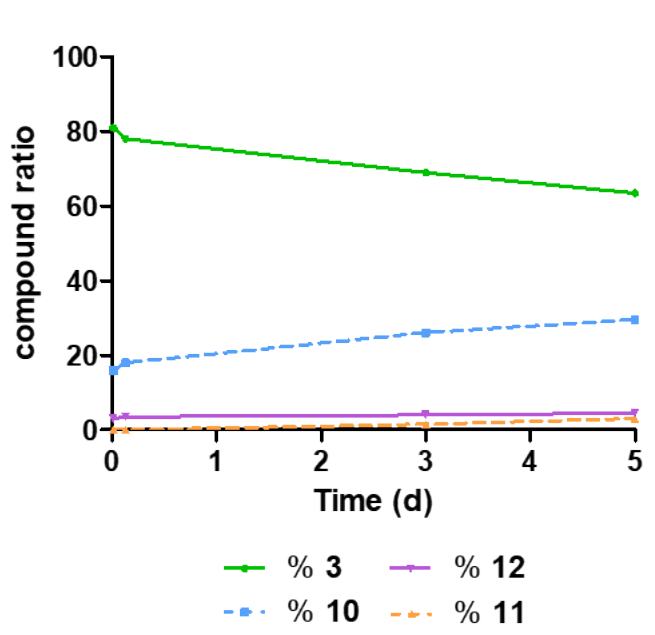<smiles>COc1ncc(-c2cc(-c3ncc(CN4CCN(C(C)C)CC4)o3)c3cn[nH]c3c2)cc1OC(C)=O</smiles>

10<smiles>CC(C)N1CCN(Cc2cnco2)CC1</smiles>

12<smiles>COc1ncc(-c2cc(-c3ncc(CN4CCN(C(C)C)CC4)o3)c3cnn(C(C)=O)c3c2)cc1OC(C)=O</smiles>

11<smiles>COc1ncc(-c2cc(-c3ncc(CN4CCN(C(C)C)CC4)o3)c3cnn(C(C)=O)c3c2)cc1O</smiles>

Figure S3 - Stability of acetate ester 3 in DMSO. Hydrolysis of $\mathbf{3}$ was monitored over time, multiple chemical entities were observed (proposed structures). The graph shows the ratio of the different compounds calculated from the normalized \% peak area recorded by LC-MS.

\section{DHB esters 5, 6 and 7}

The ester solutions were maintained at r.t. for $24 \mathrm{~h}$, and were then frozen (freezer, $-20{ }^{\circ} \mathrm{C}$ ) and thawed between subsequent LC-MS analyses. Acetate 5, isobutyrate $\mathbf{6}$ and thiopyran $\mathbf{7}$ showed little overall hydrolysis, indicating that they were amenable to long-term storage at $-20{ }^{\circ} \mathrm{C}$ (Figure S4).

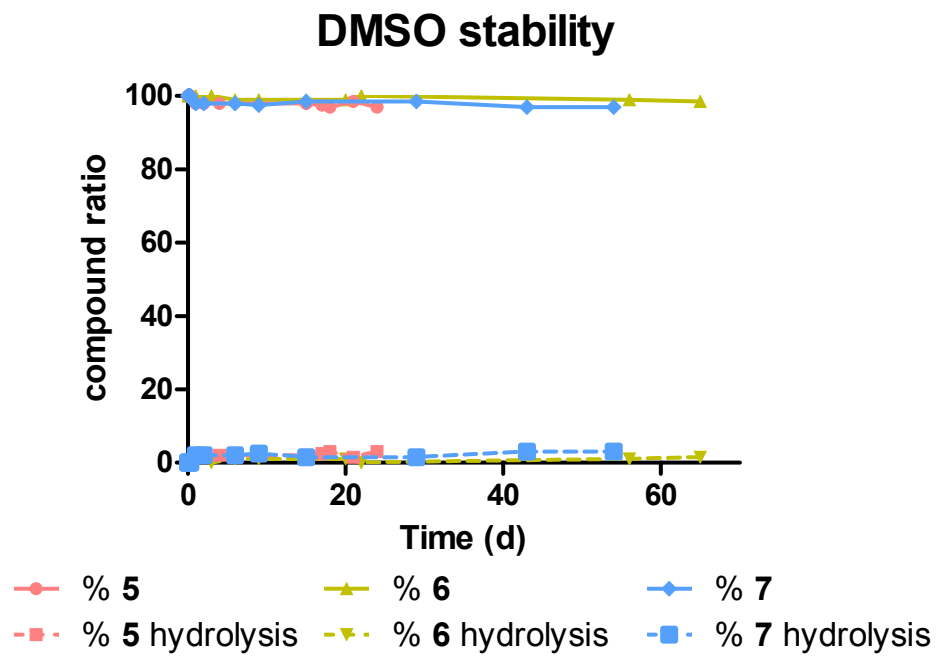

Figure S4 - Stability of esters 5, 6 and 7 in DMSO. All graphs represent the ratio of ester (solid lines) and phenol arising from ester hydrolysis (dashed lines), calculated from normalized \% peak area recorded by LC-MS. 


\section{Recombinant protein production}

\section{Production of the recombinant PI3K protein constructs}

His-p85a (regulatory subunit for recombinant PI3K $\alpha$ and PI3K $\beta$ ):

The p85var1 gene was cloned into pENTR/D-TOPO by GPS, and an LR reaction was carried out to subclone p85var1 into the Gateway baculovirus expression panel vector His-pDEST8. This generated an N-terminal 6xHis tag and an additional vector-encoded TEV cleavage site on the construct.

$\underline{\mathrm{hPI} 3 \mathrm{~K} \alpha \text { (catalytic subunit): }}$

An untagged $\mathrm{hPI} 3 \mathrm{~K} \alpha$ construct with CACC sequence upstream of the ATG was generated using PCR reaction with primers G112837 and G112838 and a template hPI3Ka construct (University of Dundee/GSK collaboration). The untagged construct was TOPO cloned into the $\mathrm{pENTR/D-TOPO} \mathrm{Gateway} \mathrm{entry} \mathrm{vector.} \mathrm{An} \mathrm{LR} \mathrm{reaction} \mathrm{was} \mathrm{carried} \mathrm{out} \mathrm{to} \mathrm{subclone} \mathrm{the}$ construct into the Gateway baculovirus expression panel vector pDEST8.

$\underline{\mathrm{hPI} 3 \mathrm{~K} \beta \text { (catalytic subunit): }}$

An untagged hPI3K $\beta$ construct with CACC sequence upstream of the ATG was generated using PCR reaction with primers G112839 and G112840 and hPI3K $\beta /$ pCDNA3.1 template. The untagged construct was TOPO cloned into the pENTR/D-TOPO Gateway entry vector. An LR reaction was carried out to subclone the construct into the Gateway baculovirus expression panel vector pDEST8.

His-p85a (1-724) (regulatory subunit for recombinant PI3K $\delta$ ):

p85a (1-724) was PCR amplified and cloned into pDNOR221. The truncate was then recombined into pDEST8 (6×His N-terminal).

\section{$\underline{\mathrm{hPI} 3 \mathrm{~K} \delta \text { (catalytic subunit): }}$}

An untagged $\mathrm{hPI} 3 \mathrm{~K} \delta$ construct with CACC sequence upstream of the ATG was generated using PCR reaction with primers G112841 and G112842 and hPI3K $\delta /$ pCDNA3.1 template. The untagged construct was TOPO cloned into the pENTR/D-TOPO Gateway entry vector. An LR reaction was carried out to subclone the construct into the Gateway baculovirus expression panel vector pDEST8. 


\section{General cell culture procedure}

For expression, Sf9 cells infected with the appropriate viruses encoding the different PI3K catalytic or regulatory subunits. The cultures were incubated at $27^{\circ} \mathrm{C}$ for $5 \mathrm{~d}$ after infection, and cells were harvested and stored covered at $4{ }^{\circ} \mathrm{C}$.

\section{Purification of PI3K $\alpha$ and PI3K $\beta$ heterodimers}

Pellets of cells co-infected with the regulatory and catalytic subunits were resuspended in lysis buffer (20 mM Tris pH 8.0, $500 \mathrm{mM} \mathrm{NaCl}, 20 \mathrm{mM}$ Imidazole, $1 \mathrm{mM} \mathrm{MgCl}$, PIC set III*) + $0.01 \% v / v$ Benzonase. The cells were disrupted by Dounce Homogenisation. The lysate was centrifuged at $100,000 \mathrm{~g}\left(90 \mathrm{~min}, 4^{\circ} \mathrm{C}\right)$. The supernatant was loaded onto a $5 \mathrm{~mL}$ HisTrap HP column pre-equilibrated with buffer A (20 mM Tris $\mathrm{pH}$ 8.0, $500 \mathrm{mM} \mathrm{NaCl}, 20 \mathrm{mM}$ Imidazole, PIC set III*). After a wash step with buffer A, the column was eluted using a gradient from 0 $100 \%$ buffer B (20 mM Tris pH 8.0, $500 \mathrm{mM} \mathrm{NaCl}, 500 \mathrm{mM}$ Imidazole, PIC set III*). Protein containing fractions were pooled and concentrated. The concentrated fractions were divided as appropriate and purified further on a $320 \mathrm{~mL}$ Superdex 200 prep grade SEC column, eluted with Buffer C (20 mM Tris pH 8.0, $150 \mathrm{mM} \mathrm{NaCl,1} \mathrm{mM} \mathrm{DTT).}$

Finally, the appropriate fractions (as determined by SDS-PAGE) were combined. Protein concentrations were determined by Bradford Assay, then the samples were aliquoted and stored at $-80{ }^{\circ} \mathrm{C}$.

* Protease Inhibitor Cocktail set III: contains AEBSF, aprotinin, bestatin, E64, leupeptin and pepstatin.

\section{Purification of the PI3Kס heterodimer}

Pellets of cells co-infected with the regulatory and catalytic subunits were resuspended in 700 $\mathrm{mL}$ lysis buffer (20 mM Tris pH 8.0, $100 \mathrm{mM} \mathrm{NaCl,} 2 \mathrm{mM} \beta$-mercaptoethanol, 5\% glycerol, Protease Inhibitor Cocktail P8340 (Sigma), $10 \mathrm{mM}$ Imidazole) and $600 \mu \mathrm{L}$ Benzonase. The cells were disrupted by Dounce Homogenisation. The lysate was centrifuged at 108,800 g (90 min, $4{ }^{\circ} \mathrm{C}$ ). The supernatant was loaded onto a $5 \mathrm{~mL}$ HisTrap HP column pre-equilibrated with buffer D (20 mM Tris pH 8.0, $100 \mathrm{mM} \mathrm{NaCl,} 2 \mathrm{mM} \beta$-mercaptoethanol, 5\% glycerol, $10 \mathrm{mM}$ Imidazole). After a wash step with buffer D, the column was eluted using a gradient from 10$500 \mathrm{mM}$ Imidazole.

Protein containing fractions were pooled and filtered, then loaded onto a $5 \mathrm{~mL}$ HiTrap Q Sepharose HP column pre-equilibrated with buffer E (20 mM Tris pH 8.0, $10 \mathrm{mM} \mathrm{NaCl}, 2 \mathrm{mM}$ 
$\beta$-mercaptoethanol, $5 \%$ glycerol). After a wash step with buffer E, the column was eluted using a gradient from $10-1000 \mathrm{mM} \mathrm{NaCl}$. Protein containing fractions were pooled and concentrated by centrifugation (final volume $15 \mathrm{~mL}$ ).

The pooled fractions were loaded onto a $320 \mathrm{~mL}$ Superdex 200 prep grade column. The column was eluted with buffer F (20 mM Tris pH 8.0, $150 \mathrm{mM} \mathrm{NaCl,} 5 \mathrm{mM}$ DTT, 10\% glycerol).

Finally, the appropriate fractions (as determined by SDS-PAGE) were combined. Protein concentrations were determined by Bradford Assay, then the samples were aliquoted and stored at $-80{ }^{\circ} \mathrm{C}$. 


\section{Intact protein LC-MS analysis}

\section{LC-MS Protocol}

Method A:

LC-MS analysis of proteins of interest was conducted on an Agilent G6224A TOF LC/MS equipped with Agilent 1200 Series autosampler. Analytes were separated on an Agilent PLRP$\mathrm{S}$ column $(50 \mathrm{~mm} \times 1 \mathrm{~mm}$ internal diameter, $5 \mu \mathrm{m}$ particle size). LC conditions were 0.5 $\mathrm{mL} / \mathrm{min}$ flow rate, $70^{\circ} \mathrm{C}, 10 \mu \mathrm{L}$ injection volume. Gradient elution with (A) water containing $0.2 \% v / v$ formic acid and (B) acetonitrile containing $0.2 \% v / v$ formic acid. Gradient conditions:

\begin{tabular}{cc} 
Time $(\mathrm{min})$ & $\% \mathrm{~B}$ \\
\hline 0.00 & 20 \\
0.50 & 20 \\
0.51 & 40 \\
2.50 & 80 \\
2.51 & 100 \\
4.00 & 100 \\
4.01 & 20 \\
4.50 & 20
\end{tabular}

\section{Method B:}

LC-MS was conducted on an Agilent G6230B TOF LC/MS equipped with Agilent Multisampler G7167B. Analytes were separated on an Agilent PLRP-S column (50 mm x 2.1 $\mathrm{mm}$ internal diameter, $8 \mu \mathrm{m}$ particle size). LC conditions were $0.5 \mathrm{~mL} / \mathrm{min}$ flow rate, $70{ }^{\circ} \mathrm{C}, 5$ $\mu \mathrm{L}$ injection volume. Gradient elution with (A) water containing $0.2 \% v / v$ formic acid and (B) acetonitrile containing $0.2 \% v / v$ formic acid. Gradient conditions:

\begin{tabular}{cc} 
Time $(\mathrm{min})$ & $\% \mathrm{~B}$ \\
\hline 0.00 & 20 \\
0.60 & 20 \\
0.61 & 50 \\
1.00 & 100 \\
1.20 & 100 \\
1.21 & 20
\end{tabular}


Mass spectra were deconvoluted using Agilent MassHunter Qualitative Analysis version B.06.00 over the mass range 850-2,200 Da to obtain the corresponding intact protein mass spectra (70-150 kDa). The deconvoluted spectra were plotted using GraphPad Prism 5.0.4 to obtain the graphs presented in this manuscript.

\section{Materials}

Recombinant human PI3K $\delta$ heterodimeric enzyme; $\mathrm{p} 85\left(\mathrm{M}_{\mathrm{W}}=86,586 \mathrm{Da}\right)$ and $\mathrm{p} 110 \delta\left(\mathrm{M}_{\mathrm{W}}=\right.$ $119,479 \mathrm{Da})$.

Samples for LC-MS were prepared in phosphate-buffered saline (PBS): $8 \% \mathrm{NaCl}, 0.2 \% \mathrm{KCl}$, $0.2 \% \mathrm{KH}_{2} \mathrm{PO}_{4}, 1.15 \% \mathrm{Na}_{2} \mathrm{HPO}_{4}$ in deionized water; the resulting solution was autoclaved, and the $\mathrm{pH}$ was adjusted to 7.2 with $\mathrm{HCl}$ (concentrations in $\% \mathrm{w} / \mathrm{w}$ ).

\section{Covalent adduct assessment experiment}

Sample preparation for LC-MS analysis of all inhibitors (phenol 9 and esters 5, 6 and 7)

$\mathrm{PI} 3 \mathrm{~K} \delta$ concentration was adjusted to $1 \mu \mathrm{M}$ in PBS. The enzyme was incubated with either 10 $\mu \mathrm{M}$ inhibitor or DMSO (reference) on ice for 5-7.5 h prior to LC-MS analysis. DMSO was normalized to $2 \%(v / v)$ for all samples. Compounds $\mathbf{9}, 5$ and 7 were analyzed with Method A; compound 6 with Method B. 

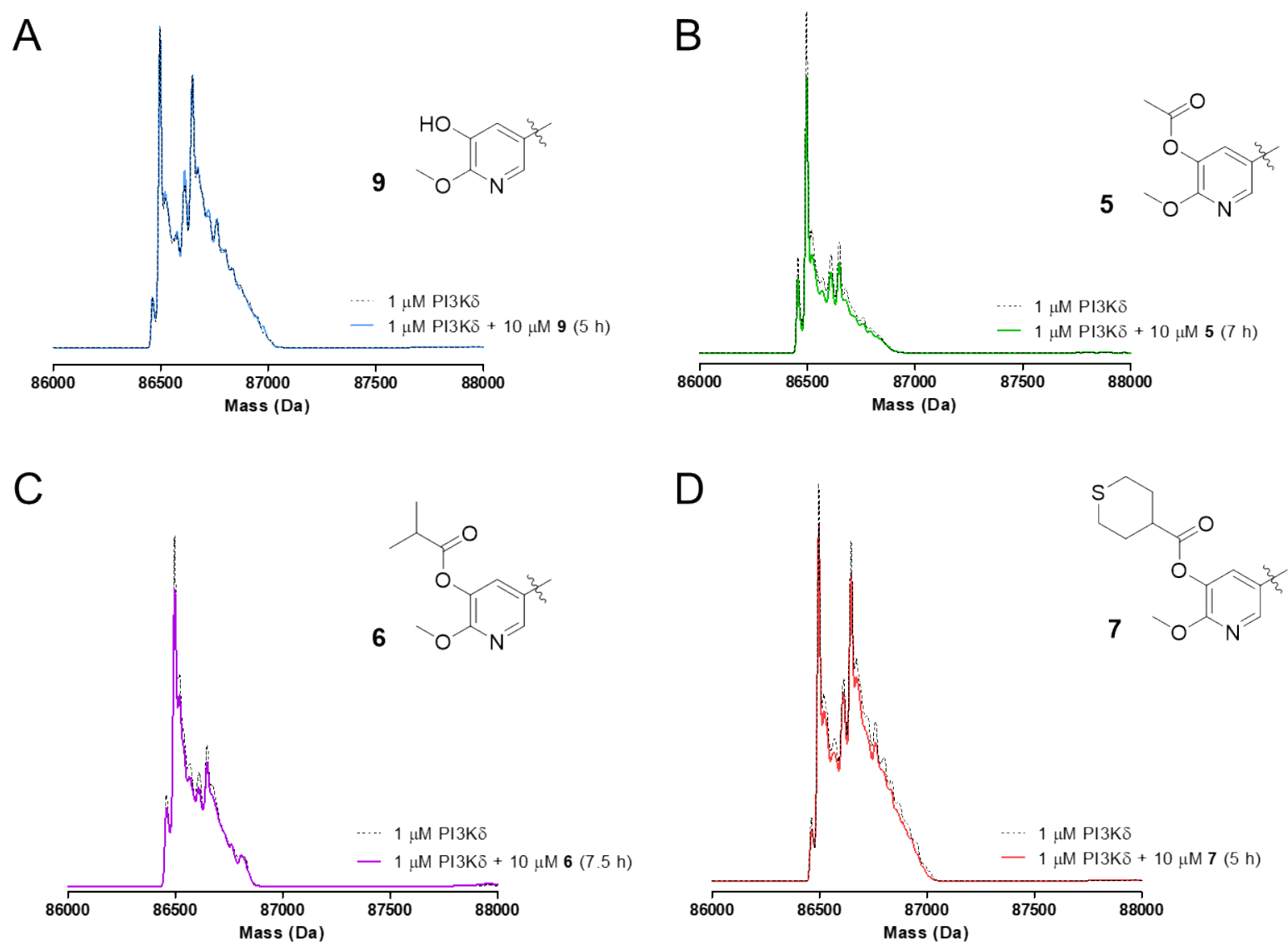

Figure S5 - LC-MS analysis of PI3K $\delta$-ester adducts. A-D) Recombinant PI3K $\delta$ samples after incubation with 10-fold excess of the DHB ligands. Deconvoluted mass spectra segments $(86,000-88,000 \mathrm{Da})$ show the regulatory p 85 subunit. The spectra obtained for the protein after incubation with the ligands (solid lines) are overlaid with a reference of the protein incubated with DMSO (dashed lines). A) PI3K $\delta+$ phenol 9; B) PI3K $\delta+$ acetyl ester 5; C) PI3K $\delta+$ isobutyrate ester 6; D) PI3K $\delta$ + tetrahydro- $2 H$-thiopyran-4-carboxylate ester 7 . No mass shifts of the $\mathrm{p} 85$ protein subunit observed with any of the tested ligands.

\section{Wortmannin competition experiment}

$\mathrm{PI} 3 \mathrm{~K} \delta$ concentration was adjusted to $1 \mu \mathrm{M}$ in PBS; compounds 1 and $\mathbf{9}$ were added from DMSO solutions. DMSO was normalized to $2 \%(v / v)$ in all samples. LC-MS recorded at regular time intervals while keeping samples at $4{ }^{\circ} \mathrm{C}$.

Wortmannin time-course: enzyme incubated with $50 \mu \mathrm{M}$ of wortmannin 1.

Competition time-course: addition of phenol 9 first $(5 \mu \mathrm{M})$, then wortmannin $1(50 \mu \mathrm{M})$ to the $\mathrm{PI} 3 \mathrm{~K} \delta$ solution.

In this competition experiment, the rate of covalent binding of 1 to $110 \delta$ was monitored by LC-MS with and without pre-incubation of phenol 9 (Figure S6). Without pre-incubation of 9 , p1 $10 \delta$ was fully modified by $\mathbf{1}$ within 5 min. However, when phenol 9 was added prior to $\mathbf{1}$, 
p1 $10 \delta$ was only partially labelled after $5 \mathrm{~min}$, indicating a slower rate of covalent modification. Full labelling of the protein by 1 was achieved between $20-35 \mathrm{~min}$ in the presence of 9 . The slower covalent modification of the protein with wortmannin $\mathbf{1}$ in the competition experiment confirmed that phenol 9 was binding to the ATP pocket. This was consistent with our initial design strategy, which aimed to maintain reversible binding interactions from the DHB core to the $\mathrm{PI} 3 \mathrm{~K} \delta$ active site.

A

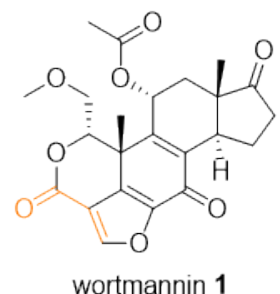

B wortmannin 1 time-course<smiles>COc1ncc(-c2cc3c(c(OCCN4CCC(C(C)(C)O)CC4)c2)COC3)cc1O</smiles>

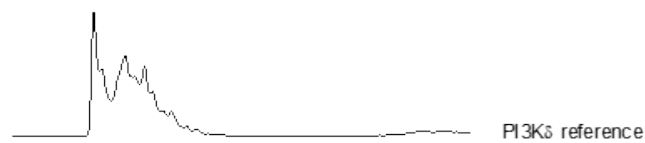

Cortmannin $1+$ phenol 9 time-course
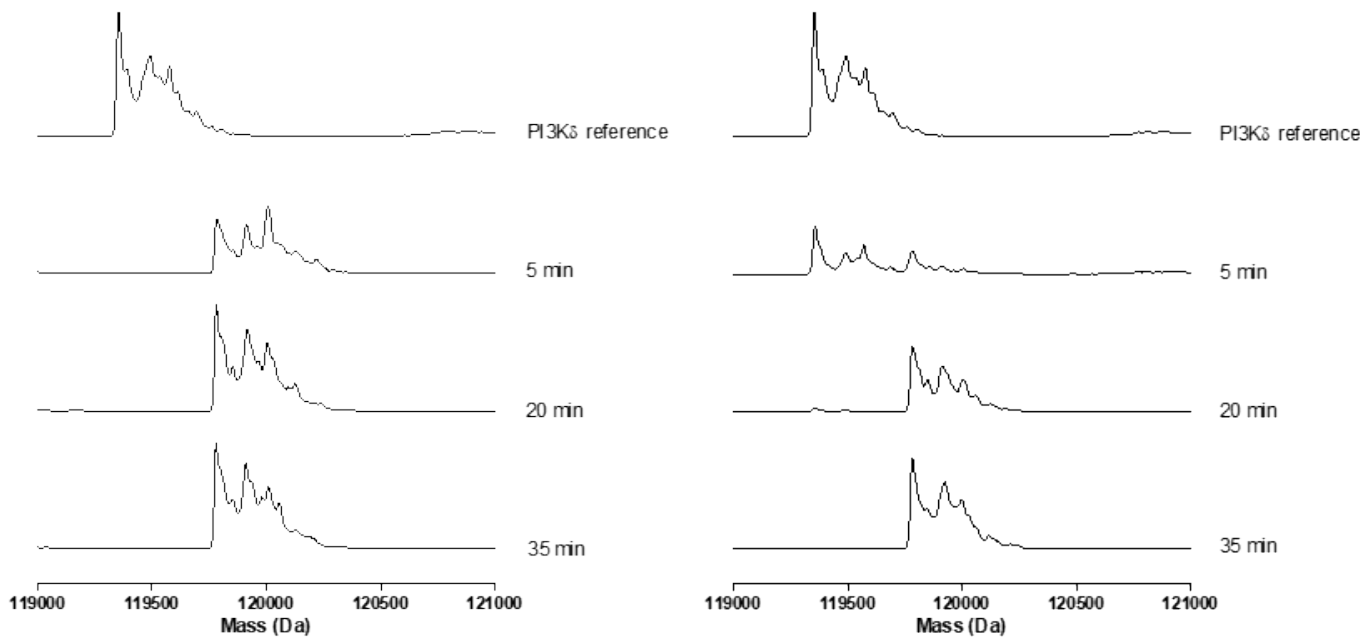

Figure S6 - Competition LC-MS assay. A) Compounds used in the protein LC-MS competition assay: wortmannin 1 and DHB phenol 9; LC-MS: B) time-course, covalent binding of 1 to $\mathrm{PI} 3 \mathrm{~K} \delta$, observed $\Delta \mathrm{M}=426 \mathrm{Da} ; \mathrm{C}$ ) competition assay, binding of wortmannin 1 to PI3K $\delta$ in the presence of phenol 9.

\section{Covalent modification of other PI3K isoforms}

An initial attempt at assessing the kinase selectivity of the compounds therefore consisted of PLC-MS experiments with class I isoforms, PI3K $\alpha$ and PI3K $\beta$. The enzymes were incubated with isobutyrate 6 (10-fold excess ester; $6.5-7 \mathrm{~h} ; 4^{\circ} \mathrm{C}$ ), prior to PLC-MS analysis. Due to the weaker $\mathrm{pIC}_{50}$ values obtained against PI3K $\alpha$ and $\mathrm{PI} 3 \mathrm{~K} \beta$ compared to PI3K $\delta$ in the TR-FRET assay, we expected to observe less covalent labelling of PI3K $\alpha$ and PI3K $\beta$ in this experiment. However, ester 6 showed full labelling of PI3K $\alpha$ and PI3K $\beta$ under these conditions (Figure S7). 

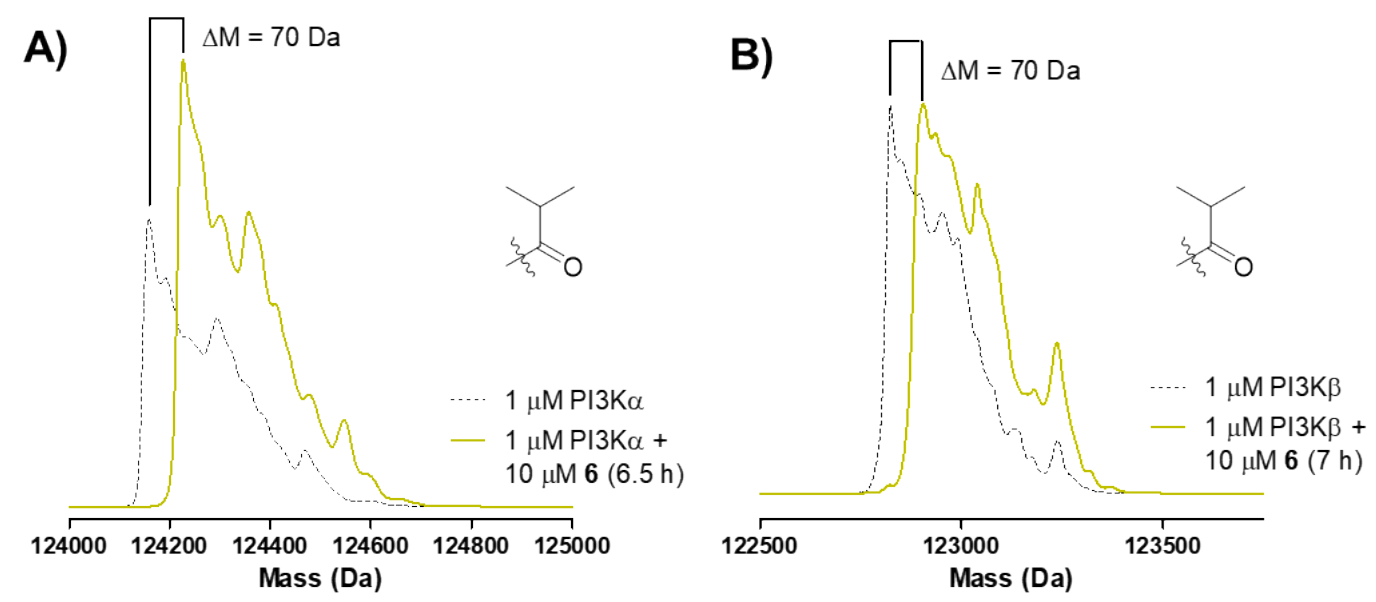

Figure S7 - LC-MS analysis of PI3K-ester adducts. Both graphs highlight $\Delta \mathrm{M}$ between labelled enzyme (solid line) and a reference sample of intact enzyme (dashed line). A) PI3Ka: deconvoluted mass spectra of the p110 $\alpha$ subunit $\left(124,000-125,000 \mathrm{Da}\right.$; expected $\mathrm{M}_{\mathrm{W}}=$ $124,285 \mathrm{Da})$; B) PI3K $\beta$ : deconvoluted mass spectra of the $\mathrm{p} 110 \beta$ subunit $(122,500-123,750$ $\mathrm{Da}$; expected $\left.\mathrm{M}_{\mathrm{W}}=122,762 \mathrm{Da}\right)$.

The intact protein mass spectrometry results showed no apparent selectivity of the isobutyrate ester 6 for a specific PI3K isoform, under the experimental conditions described. In the chemoproteomic kinobead assay, $\mathrm{PI} 3 \mathrm{~K} \alpha$ and $\mathrm{PI} 3 \mathrm{~K} \beta$ were not detected as significant off-targets of isobutyrate ester $\mathbf{6}$, which could appear contradictory. However, the experimental conditions between both assays are sufficiently different to explain this. In the LC-MS experiment, pure recombinant enzymes were incubated with 10-fold excess of the activated ester for a longer period ( $7 \mathrm{~h}$ ), in a simplified media (PBS). The lipid kinobead assay evaluates binding affinities in a more physiologically relevant context because it is carried out in cell lysates. The lysates contain multiple kinases, each present at different concentrations, as well as numerous cellular co-factors. The cell lysates were exposed to a gradient of increasing compound concentration $(80 \mathrm{pM}-30 \mu \mathrm{M})$. In this context, the chemoproteomics assay affords a more physiologically relevant representation of the compound's selectivity profile across a portion of the kinome, whereas the LC-MS experiments correspond to forcing conditions for the covalent acylation reaction. The combined chemoproteomics and LC-MS results indicate that isobutyrate ester 6 is a competent covalent modifier of multiple class I PI3K isoforms, however, it shows a distinct binding preference towards PI3K $\delta$ compared to closely related lipid kinases in cell lysates. 


\section{Identification of modification site(s) by LC-MS/MS}

\section{Sample preparation:}

The covalent binding site of ester 5 was identified using recombinant human PI3K $\delta$. Protein samples $(5 \mu \mathrm{M})$ were incubated with acetate ester $5(10 \mu \mathrm{M})$ or DMSO (control) for $4 \mathrm{~h}$ at $4{ }^{\circ} \mathrm{C}$; DMSO was normalized to $2 \% v / v$.

Samples $(5 \mu \mathrm{g})$ were separated by SDS-PAGE to remove the excess of unbound compound and separate the $\mathrm{p} 85 \alpha$ and $\mathrm{p} 110 \delta$ protein subunits. The gel was stained with colloidal Coomassie InstantBlue and bands corresponding to $110 \delta$ or p 85 were excised and reduced with $10 \mathrm{mM}$ TCEP (30 min; $65^{\circ} \mathrm{C}$ ) and alkylated with $10 \mathrm{mM}$ iodoacetamide (30 min; r.t.; dark). The p85

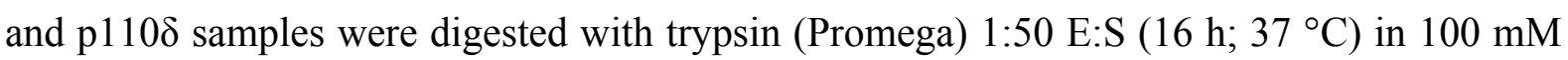
ammonium bicarbonate. Following trypsin digestion, the $\mathrm{p} 110 \delta$ samples were further digested with GluC (Roche) 1:50 E:S $\left(2.5 \mathrm{~h} ; 37^{\circ} \mathrm{C}\right)$. After removal of the supernatant, peptides were extracted using acetonitrile. Combined supernatants were concentrated in a Gyro Vap centrifuge and acidified ( $0.1 \% v / v$ formic acid) prior to injection into the LC-MS/MS system.

\section{LC-MS/MS analysis:}

Digested samples were injected on an Easy nLC1000 UHPLC system (Thermo Scientific). Peptides were loaded on a $2 \mathrm{~cm}$ x $75 \mu \mathrm{m}$ Acclaim PepMap $100 \mathrm{C} 18$ trapping column (Thermo Scientific) and separated on a $25 \mathrm{~cm}$ x $75 \mu \mathrm{m}, 2 \mu \mathrm{m}$ particles, PepMap C18 column (Thermo Scientific) using a $50 \mathrm{~min}$ gradient of $2-38 \%$ acetonitrile, $0.2 \%$ formic acid and a flow of 300 $\mathrm{nL} \cdot \mathrm{min}^{-1}$. LC-MS/MS based peptide sequencing was performed by data dependent analysis (DDA) (full MS 350-1600 Da at 70,000 resolution, MS AGC target 1e6, MS Maximum IT $200 \mathrm{~ms}$ ), followed by MS/MS (top $10 \mathrm{HCD}$ fragmentation, stepped normalized CE 23, 27 and $30 \mathrm{~V}$, Isolation window $1.5 \mathrm{~m} / \mathrm{z}$, fixed first mass $145 \mathrm{~m} / \mathrm{z}, 17,500$ resolution, MS/MS AGC target 5e4 and MS/MS Maximum IT $200 \mathrm{~ms}$ ).

Data was acquired and elaborated using Xcalibur 4.0.27.19.

Uninterpreted spectra were searched for peptide matches against the $p 110 \delta$ sequence with the Mascot Software (Matrix Science; version 2.6.0) using a 5 ppm mass tolerance for peptide precursors and $20 \mathrm{mDa}$ mass tolerance for fragment ions. Raw files were searched using trypsin plus Glu-C as the enzyme. Acetylation on Lys and protein N-terminus as well as oxidation on Met, and Asn/Gln deamidation were allowed as variable modifications. Carbamidomethylation on Cys was selected as fixed modification. MS/MS spectra relative to the modified peptide was manually validated to ensure exact assignment of the site of modification. 
LC-MS/MS peptide mapping confirmed K779 as the covalent binding site of ester $\mathbf{5}$ on the $\mathrm{PI} 3 \mathrm{~K} \delta$-p $110 \delta$ sequence, after comparing the data obtained from the treated sample and DMSO control sample.

LC-MS/MS peptide mapping was also conducted on the p85 subunit to identify potential labelling sites; this did not show any substantial labelling compared with the untreated control. These results indicate that the recombinant PI $3 \mathrm{~K} \delta$ heterodimer has been selectively acetylated at K779 on the p110 $\delta$ after treatment with acetate ester 5. 


\section{TR-FRET Assay}

The assay was carried out with recombinant human PI3K $\alpha, \beta$ and $\delta$ (as described previously), and recombinant human PI3K $\gamma$ (144-1102)-His (Proteros, PR-0185).

Inhibition of PI3K enzymatic activity was determined using a TR-FRET assay kit based on the method described by Gray et. al. ${ }^{2}$ The TR-FRET assay measures the APC emission signal to monitor kinase activity in the presence of an inhibitor. Reactions were performed in assay buffer containing $50 \mathrm{mM}$ HEPES, pH 7.0, $150 \mathrm{mM} \mathrm{NaCl}, 10 \mathrm{mM} \mathrm{MgCl}_{2}, 2.3 \mathrm{mM}$ sodium cholate, $10 \mu \mathrm{M}$ CHAPS, and $1 \mathrm{mM}$ DTT. Enzymes were preincubated with the tested compounds, serially diluted 4-fold in $100 \% \mathrm{DMSO}$, for $15 \mathrm{~min}$ prior to reaction initiation upon addition of substrate solution containing ATP at $K_{\mathrm{m}}$ for the specific isoform tested ( $\alpha$ at 250 $\mu \mathrm{M}, \beta$ at $400 \mu \mathrm{M}, \delta$ at $80 \mu \mathrm{M}$, and $\gamma$ at $15 \mu \mathrm{M}), \mathrm{PIP}_{2}$ at either $5 \mu \mathrm{M}(\mathrm{PI} 3 \mathrm{~K} \delta)$ or $8 \mu \mathrm{M}(\mathrm{PI} 3 \mathrm{~K} \alpha$, $\beta$, and $\gamma$ ) and $10 \mathrm{nM}$ biotin-PIP ${ }_{3}$. Assays were quenched after $60 \mathrm{~min}$ by addition of a stop / detect solution prepared in $50 \mathrm{mM}$ HEPES, $\mathrm{pH} 7.0,150 \mathrm{mM} \mathrm{NaCl}, 2.3 \mathrm{mM}$ sodium cholate, $10 \mu \mathrm{M}$ CHAPS, $30 \mathrm{mM}$ EDTA, $40 \mathrm{mM}$ potassium fluoride, and $1 \mathrm{mM}$ DTT containing 16.5 nM GST-tagged PH domain, $8.3 \mathrm{nM}$ streptavidin-APC, and $2 \mathrm{nM} \mathrm{Eu-anti-GST}$ and were left for a further $60 \mathrm{~min}$ in the dark to equilibrate prior to reading using a Perkin Elmer EnVision plate reader $\left(\lambda_{\mathrm{ex}}=340 \mathrm{~nm}, \lambda_{\mathrm{em} 1}=620 \mathrm{~nm}, \lambda_{\mathrm{em} 2}=655 \mathrm{~nm}\right)$. Ratio data (acceptor emission at $655 \mathrm{~nm}$ over the donor emission at $620 \mathrm{~nm}$ ) were normalized to high (DMSO) and low (no enzyme or enzyme in the presence of $8.3 \mu \mathrm{M}$ wortmannin) controls prior to fitting using a logistical four-parameter equation (1) to determine $\mathrm{IC}_{50}$ and $\mathrm{pIC}_{50}$ values (2).

$$
y=B+\frac{T-B}{1+\left(\frac{x}{I C_{50}}\right)^{H}}
$$

With $y$ : assay response

$B$ : lowest plateau of the curve

$T$ : highest plateau of the curve

$x$ : molar concentration of the inhibitor

$\mathrm{H}$ : hill slope

$$
\mathrm{pIC}_{50}=-\log _{10}\left(\mathrm{IC}_{50}\right)
$$




\section{Jump-Dilution Assay}

\section{Materials}

ATP: commercially available (Sigma-Aldrich); required scrubbing to remove any contaminating ADP which would interfere with the jump-dilution assay fluorescence read-out. ATP scrubbing procedure: dissolve ATP in Milli-Q water. In an Eppendorf tube, add $75 \mu \mathrm{L}$ immobilized catalase and wash with water (x 3). Remove final wash and add 25 mM ATP, 50 mM HEPES, 1 mM PEP, $50 \mathrm{mM} \mathrm{Na}_{2} \mathrm{HPO}_{4}, 50 \mathrm{mM} \mathrm{MgCl} 2,1 \mathrm{mM}$ TPP, $5 \mu \mathrm{M}$ FAD, $250 \mathrm{U} / \mathrm{mL}$ pyruvate kinase and $80 \mathrm{U} / \mathrm{mL}$ pyruvate oxidase (complete to $1.5 \mathrm{~mL}$ in Milli-Q water). Mix for $30 \mathrm{~min}$ then centrifuge ( $5 \mathrm{~min}$ at $12,000 \mathrm{rpm}$ ). Carefully aliquot the supernatant, containing the scrubbed ATP.

PIP2: Phosphatidylinositol 4,5-bisphosphate (diC8); $1 \mathrm{mM}$ aqueous stock solution prepared from commercially available product (Echelon Biosciences; catalogue reference P-4508)

PI3K reaction buffer: 50 mM HEPES pH $7.0(\mathrm{NaOH}), 150 \mathrm{mM} \mathrm{NaCl}, 10 \mathrm{mM} \mathrm{MgCl} 2,2.3 \mathrm{mM}$ sodium cholate, $10 \mu \mathrm{M}$ CHAPS

ADP Quest ${ }^{\mathrm{TM}}$ detection reagents A and B (DiscoverX, catalogue number: 90-0071)

Assay buffer: $1 \mathrm{mM}$ ATP, $40 \mu \mathrm{M}$ PIP2, 26.65\% $(v / v)$ reagent A, 53.3\% $(v / v)$ reagent B, in PI3K reaction buffer

\section{IC $_{50}$ measurements:}

Prior to the jump-dilution, experimental $\mathrm{IC}_{50}$ values were determined for each inhibitor using the ADP Quest ${ }^{\mathrm{TM}}$ assay conditions. Assay buffer was added to the compounds, serially diluted 2-fold in $100 \%$ DMSO, in a 384 -well plate (DMSO was normalized to $1 \%(v / v)$ of the final assay volume). The plate was centrifuged to $1,000 \mathrm{rpm}(1 \mathrm{~min})$, prior to addition of $\mathrm{PI} 3 \mathrm{~K} \delta$ $(5 \mathrm{nM})$. The plate was centrifuged a second time to $1,000 \mathrm{rpm}(1 \mathrm{~min})$.

Enzyme activity, characterised by an increase in fluorescence intensity (RFU: Relative Fluorescence Units), was monitored continuously using a Tecan Safire II plate reader at $30 \mathrm{~s}$ intervals for 41 kinetic cycles $\left(\lambda_{\mathrm{ex}}=544 \mathrm{~nm}, \lambda_{\mathrm{em}}=590 \mathrm{~nm}\right)$.

Data was analyzed using GraphPad Prism (version 5.0.4). RFU at 25 min was plotted against inhibitor concentration prior to fitting using a logistical four-parameter equation to determine 
$\mathrm{IC}_{50}$ values. The data for compounds $\mathbf{9 , 5 , 6}$ and $\mathbf{7}$ is presented in Table $\mathrm{S} 1$ as an average of three independent replicates.

\section{Jump dilution Protocol:}

$\mathrm{PI} 3 \mathrm{~K} \delta$ concentration was adjusted to $500 \mathrm{nM}$ in PI3K reaction buffer. The enzyme was preincubated with phenol $9(0.6 \mu \mathrm{M})$, acetyl ester $5(0.6 \mu \mathrm{M})$, isobutyrate ester $6(2.2 \mu \mathrm{M})$ or tetrahydro- $2 H$-thiopyran-4-carboxylate ester $7(3.73 \mu \mathrm{M})$ at r.t. in a 384 well plate. Pre-incubation included high control (no inhibitors) and low control (no enzyme) wells. Each pre-incubation condition was duplicated; DMSO was normalized to $1 \%(v / v)$ in all preincubation wells. After $25 \mathrm{~min}, 1 \mu \mathrm{L}$ of each pre-incubated mixture was transferred to a 384 black-bottom deep-well plate (in triplicate). Solutions were diluted 100-fold in assay buffer and the plate was centrifuged to $1,000 \mathrm{rpm}(1 \mathrm{~min})$.

Enzyme activity, characterised by an increase in fluorescence intensity (RFU), was monitored continuously using a Tecan Safire II plate reader at $30 \mathrm{~s}$ intervals for $1 \mathrm{~h}\left(\lambda_{\mathrm{ex}}=544 \mathrm{~nm}, \lambda_{\mathrm{em}}=\right.$ $590 \mathrm{~nm})$.

\section{Analysis:}

Data was analyzed using GraphPad Prism (version 5.0.4). RFU was plotted against time after zero-correction to evaluate each inhibitor and control as an average of all replicates. The data were fitted using a linear regression model to extrapolate curve slopes between 300-1980 s, and calculate the proportion of enzyme activity (\%A) recovered relative to the high and low controls (Table S1). Values for $\% \mathrm{~A}$ were compared with model predictions $\% \mathrm{~A}_{\text {preinc }}$ and $\% \mathrm{~A}_{\max }$.

Values for $\% \mathrm{~A}$ were calculated as such:

$$
\% \mathrm{~A}_{\text {inhibitor }}=100 *\left(\text { Slope }_{\text {inhibitor }}-\text { Slope }_{\text {low control }}\right) /\left(\text { Slope }_{\text {high control }}-\text { Slope }_{\text {low control }}\right)
$$

Model predictions: the following equation was used to predict $\% \mathrm{~A}_{\text {preinc }}$ and $\% \mathrm{~A}_{\max }$ from experimental $\mathrm{IC}_{50}$ values and 4 parameter logistic equation:

$$
y=d+\frac{a-d}{1+\left(\frac{x}{c}\right)^{b}}
$$


With $\quad \mathrm{y}: \% \mathrm{~A}_{\text {preinc }}$ or $\% \mathrm{~A}_{\max }$

d: 100 (maximum possible activity)

a: 0 (minimum possible activity)

$\mathrm{x}$ : inhibitor concentration at either pre-incubation or assay conditions (in $\mathrm{M}$ )

c: experimental $\mathrm{IC}_{50}$ (in $\mathrm{M}$ )

b: -1 (theoretical hill slope)

Table S1 - Jump-dilution results

\begin{tabular}{|c|c|c|c|c|c|c|}
\hline Conditions & $\mathbf{R}^{2}$ & Slope (RFU/s) & $\% \mathbf{A}$ & $\% A_{\text {preinc }}$ & $\% \mathbf{A}_{\max }$ & $\mathrm{IC}_{50}(\mu \mathrm{M})$ \\
\hline \multirow{3}{*}{$\begin{array}{l}\text { high } \\
\text { control }\end{array}$} & $0.9847^{*}$ & $1.480 \pm 0.021 *$ & $100 *$ & \multirow{3}{*}{-} & \multirow{3}{*}{-} & \multirow{3}{*}{-} \\
\hline & 0.8793 & $1.402 \pm 0.055$ & 100 & & & \\
\hline & 0.9238 & $1.526 \pm 0.047$ & 100 & & & \\
\hline \multirow{3}{*}{ low control } & 0.3083 & $0.014 \pm 0.002$ & 0 & \multirow{3}{*}{-} & \multirow{3}{*}{-} & \multirow{3}{*}{-} \\
\hline & 0.7066 & $0.025 \pm 0.002$ & 0 & & & \\
\hline & 0.8984 & $0.026 \pm 0.001$ & 0 & & & \\
\hline \multirow{3}{*}{9} & 0.9338 & $0.862 \pm 0.024$ & 58 & \multirow{3}{*}{1} & \multirow{3}{*}{34} & \multirow{3}{*}{0.0031} \\
\hline & 0.9478 & $0.925 \pm 0.023$ & 65 & & & \\
\hline & 0.954 & $1.026 \pm 0.024$ & 67 & & & \\
\hline \multirow{3}{*}{5} & 0.5104 & $0.039 \pm 0.004$ & 2 & \multirow{3}{*}{1} & \multirow{3}{*}{39} & \multirow{3}{*}{0.0038} \\
\hline & 0.9307 & $0.101 \pm 0.003$ & 6 & & & \\
\hline & 0.7872 & $0.081 \pm 0.005$ & 4 & & & \\
\hline \multirow{3}{*}{6} & 0.8708 & $0.245 \pm 0.010$ & 16 & \multirow{3}{*}{3} & \multirow{3}{*}{74} & \multirow{3}{*}{0.0636} \\
\hline & 0.879 & $0.033 \pm 0.013$ & 22 & & & \\
\hline & 0.9815 & $0.306 \pm 0.005$ & 19 & & & \\
\hline \multirow{3}{*}{7} & 0.9286 & $0.550 \pm 0.016$ & 37 & \multirow{3}{*}{2} & \multirow{3}{*}{64} & \multirow{3}{*}{0.0656} \\
\hline & 0.9775 & $0.597 \pm 0.010$ & 42 & & & \\
\hline & 0.9133 & $0.543 \pm 0.018$ & 34 & & & \\
\hline
\end{tabular}

Data summary from 3 independent replicates of jump dilution: $\mathrm{R}^{2}$ and slopes were extrapolated from linear regression models; slopes are expressed with $95 \%$ confidence intervals; \%A values were calculated from slopes; $\% \mathrm{~A}_{\text {preinc }}$ and $\% \mathrm{~A}_{\max }$ are model predictions; $\mathrm{IC}_{50}$ values were derived from a previous assay. All $\mathrm{R}^{2}$, slopes and \%A obtained from mean results of 6 wells in each assay except where signaled by * which were obtained from 5 wells. 


\section{Determination of kinetic and thermodynamic parameters of the covalent inhibition mechanism}

The thermodynamic and kinetic parameters which characterise the covalent inhibition of PI3K $\delta$ ( $K_{\mathrm{I}}$ and $\left.k_{\text {inact }}\right)$ by the DHB esters $\mathbf{5}, \mathbf{6}$, and 7 were determined from time-dependent $\mathrm{IC}_{50}$ values, using the method described by Krippendorff et al. ${ }^{3}$

Time-dependent $\mathrm{IC}_{50}$ values for the esters were acquired in preparation for the jump-dilution assay (see " $\mathrm{IC}_{50}$ measurements" in the previous section). The concentration-response assay results for each test well were expressed as \% inhibition, using the following normalization equation:

$$
x=\frac{100-(100(a-b))}{c-b}
$$

where ' $a$ ' is the response at a given inhibitor concentration, ' $b$ ' is the average response of the $100 \%$ inhibition control wells, and ' $\mathrm{c}$ ' is the average response of the $0 \%$ inhibition control wells.

Curve fitting was performed using a logistical four-parameter equation (see "TR-FRET assay") to determine $\mathrm{IC}_{50}$ values, which were plotted as a function of time in GraphPad Prism 8. Values for $K_{\mathrm{I}}$ and $k_{\text {inact }}$ were then determined by fitting the model to the implicit equation below:

$$
\begin{gathered}
y=\left(\left(\left(1+\left(\mathrm{S} / K_{\mathrm{m}}\right)\right) * K_{\mathrm{I}}\right) /\left(\left(\left(k_{\text {inact }} *\left(y /\left(\left(K_{\mathrm{I}} *\left(1+\left(\mathrm{S} / K_{\mathrm{m}}\right)\right)\right)+y\right)\right)\right) * x\right) /\left(\left(2-\left(\left(k_{\text {inact }} *\left(y /\left(\left(K_{\mathrm{I}} *\left(1+\left(\mathrm{S} / K_{\mathrm{m}}\right)\right)\right)+y\right)\right)\right) * x\right)\right)-(2 * \exp ((((-\right.\right.\right. \\
\left.\left.\left.\left.\left.\left.1) * k_{\text {inact }} *\left(y /\left(\left(K_{\mathrm{I}} *\left(1+\left(\mathrm{S} / K_{\mathrm{m}}\right)\right)\right)+y\right)\right)\right) * x\right)\right)\right)\right)\right)
\end{gathered}
$$

where the variable $\mathrm{x}$ represents the timepoints, $\mathrm{y}$ the measured $\mathrm{IC}_{50}$ values, $\mathrm{S}$ the concentration of ATP in the assay $(1,000 \mu \mathrm{M})$, and $K_{\mathrm{m}}=80 \mu \mathrm{M}$.

A summary of the results obtained for DHB esters 5, 6, and 7 is shown below, for each independent replicate of the assay. 
Acetate ester 5

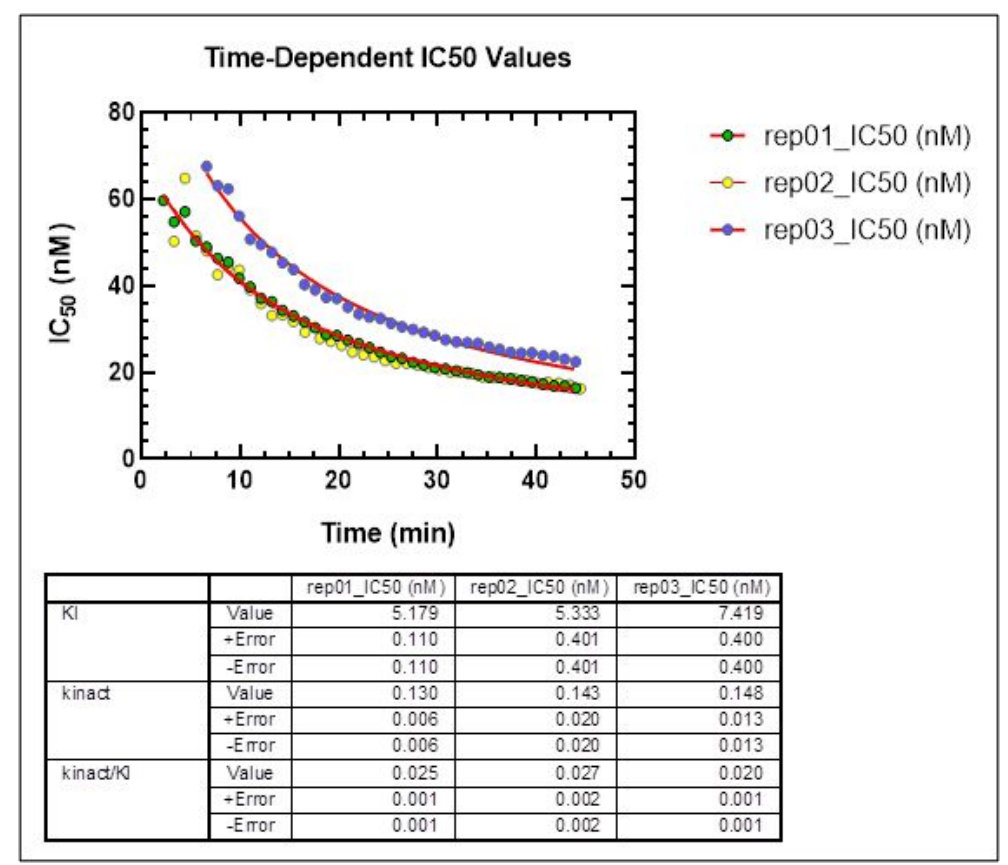

Figure S8 - Kinetic measurements for 5, from 3 independent replicates. Table shows $K_{\mathrm{I}}(\mathrm{nM})$, $k_{\text {inact }}\left(\mathrm{min}^{-1}\right)$, and $k_{\text {inact }} / K_{\mathrm{I}}\left(\mathrm{min}^{-1} \mathrm{nM}^{-1}\right)$ expressed with $95 \%$ confidence intervals.

Isobutyrate ester 6

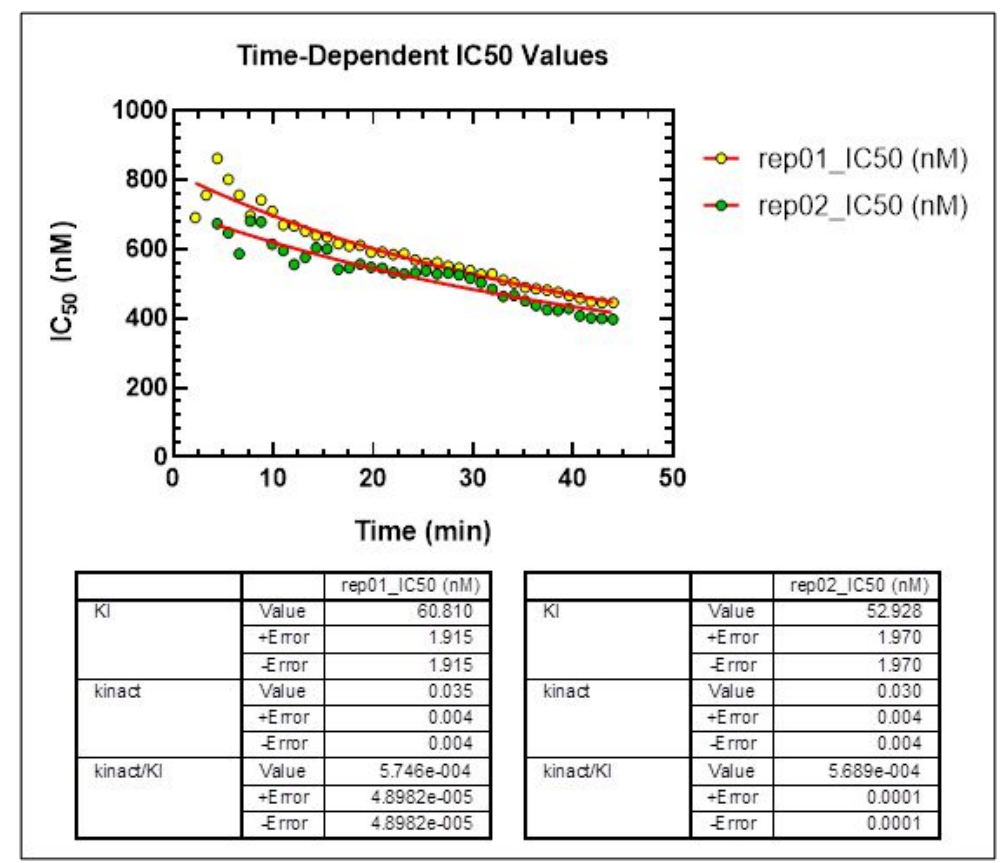

Figure S9 - Kinetic measurements for $\mathbf{6}$, from 2 independent replicates. Table shows $K_{\mathrm{I}}(\mathrm{nM})$, $k_{\text {inact }}\left(\mathrm{min}^{-1}\right)$, and $k_{\text {inact }} / K_{\mathrm{I}}\left(\mathrm{min}^{-1} \mathrm{nM}^{-1}\right)$ expressed with $95 \%$ confidence intervals. 
Thiopyran ester 7

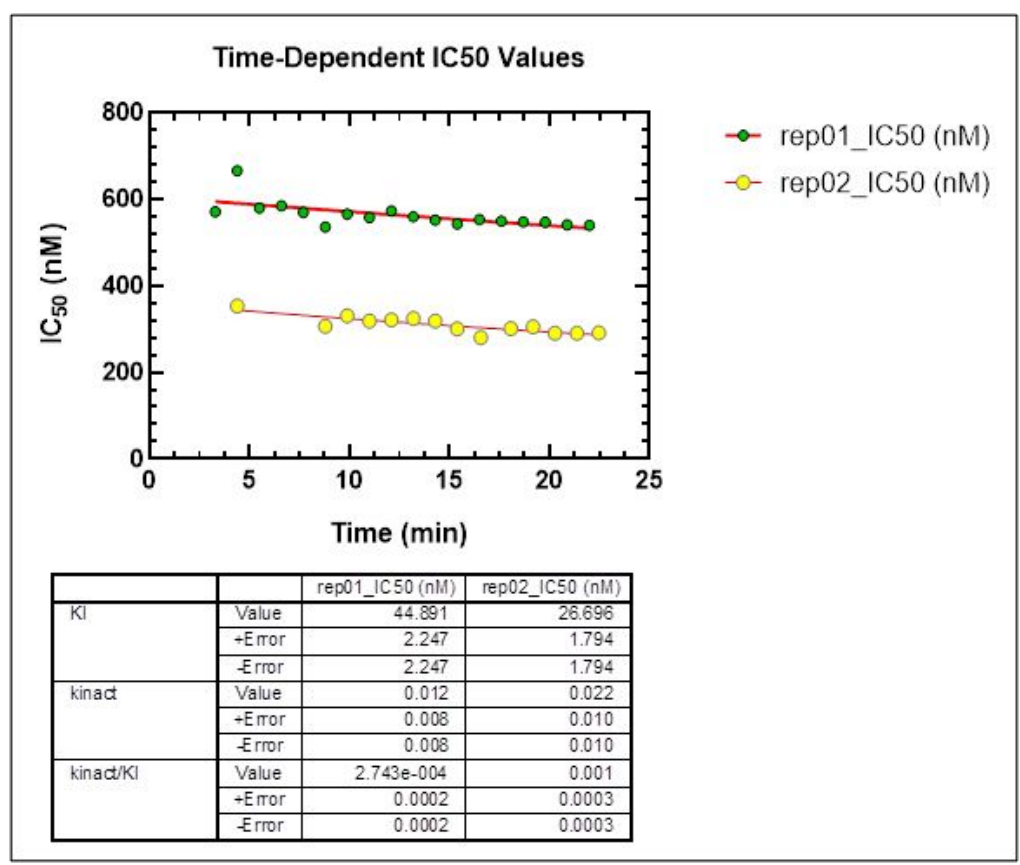

Figure S10 - Kinetic measurements for 7, from 2 independent replicates. Table shows $K_{\mathrm{I}}(\mathrm{nM})$, $k_{\text {inact }}\left(\mathrm{min}^{-1}\right)$, and $k_{\text {inact }} / K_{\mathrm{I}}\left(\mathrm{min}^{-1} \mathrm{nM}^{-1}\right)$ expressed with $95 \%$ confidence intervals. 


\section{Chemoproteomic kinobead binding assay}

\section{Hydrolytic stability assessment:}
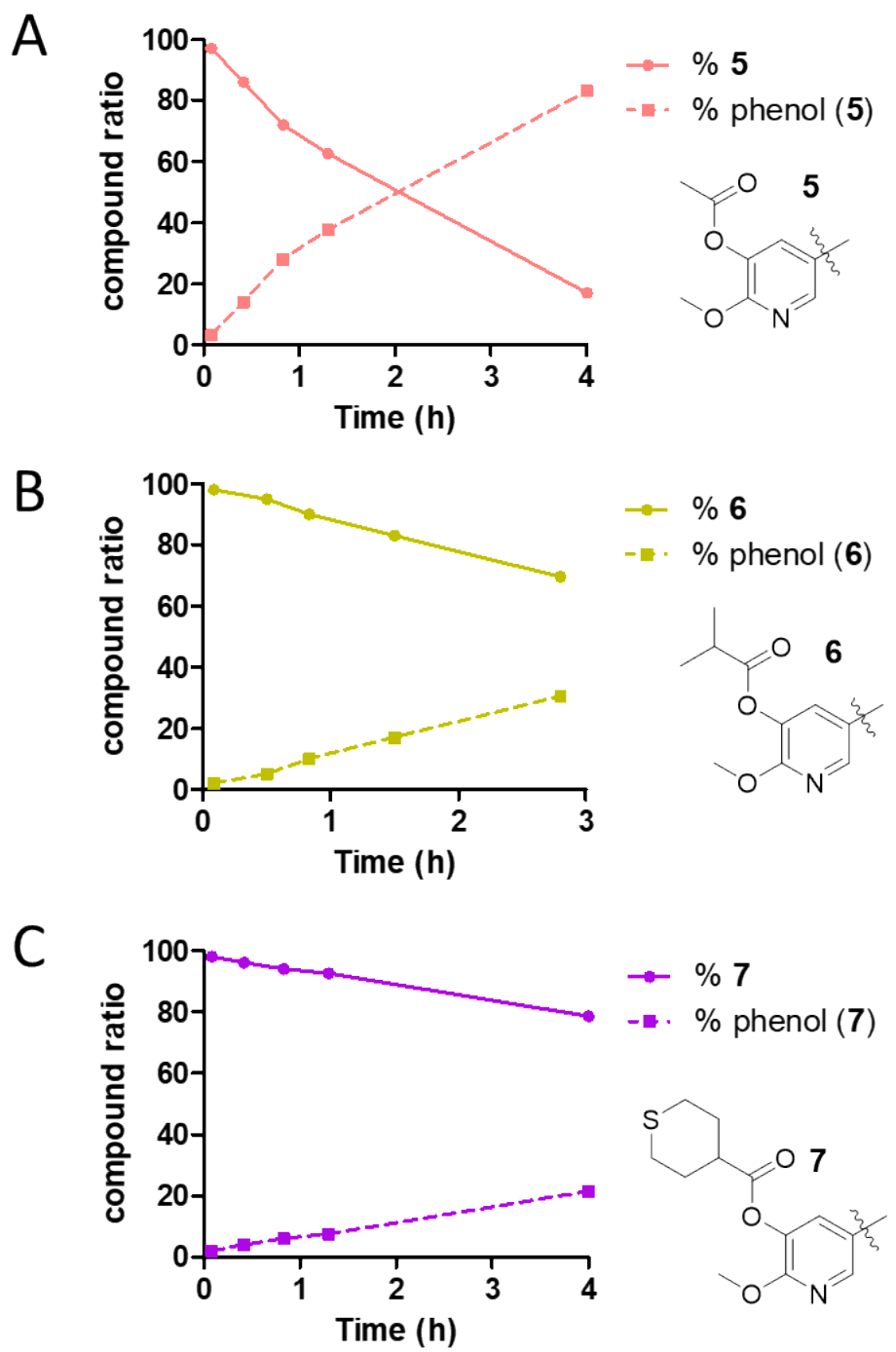

Figure S11 -Stability of esters 5, 6 and 7 over time. A-C) All graphs represent the ratio of ester (solid lines) and phenol issued from ester hydrolysis (dashed lines), calculated from normalized $\%$ peak area recorded by LC-MS.

Aqueous solutions were prepared by diluting the DMSO ester solutions in the assay buffer (50 $\mathrm{mM}$ Tris- $\mathrm{HCl} \mathrm{pH} 8.0,5 \%$ v/v glycerol, $1.5 \mathrm{mM} \mathrm{MgCl}_{2}, 150 \mathrm{mM} \mathrm{NaCl}, 1 \mathrm{mM} \mathrm{Na}_{3} \mathrm{VO}_{4}, 25 \mathrm{mM}$ $\mathrm{NaF}, 1 \mathrm{mM}$ DTT). The solutions were maintained on ice between LC-MS measurements. Results are shown in Figure S10.

LC-MS samples:

- $\quad 20 \mu \mathrm{L}$ ester solution in $\mathrm{KB}$

- $\quad 30 \mu \mathrm{L}$ internal standard (0.2 $\mathrm{mM}$ fluorene in acetonitrile) 
Analysis of the LC-MS data: similar to "Hydrolytic stability assessment" section.

\section{Cells and lysis}

K562, HeLa and Jurkat cells were derived from ATCC, cultured according to vendors instructions.

Frozen cell pellets were homogenized in 2 pellet volumes lysis buffer $(50 \mathrm{mM}$ Tris- $\mathrm{HCl}, 0.8 \%$ NP-40 ((octylphenoxypoly(ethyleneoxy)ethanol)), 5\% glycerol, $150 \mathrm{mM} \mathrm{NaCl}, 1.5 \mathrm{mM}$ $\mathrm{MgCl}_{2}, 25 \mathrm{mM} \mathrm{NaF}, 1 \mathrm{mM}$ sodium vanadate, $1 \mathrm{mM}$ DTT, $\mathrm{pH}$ 7.5) supplemented with EDTAfree protease inhibitors (one complete tablet (Roche) per $25 \mathrm{~mL}$ ) by pipetting the cell suspension 20x up and down using a $200 \mu \mathrm{L}$ pipette and gel loader tips (Steinbrenner, \#952$200 \mathrm{G})$. Crude lysate was centrifuged at $100,000 \mathrm{~g}\left(1 \mathrm{~h} ; 4^{\circ} \mathrm{C}\right)$. The protein concentration was determined by Bradford assay (BioRad), and lysates were snap frozen in liquid nitrogen and stored at $-80{ }^{\circ} \mathrm{C}$.

\section{Kinase enrichment}

Amino-functionalized kinase inhibitors were coupled to NHS activated Sepharose (GE Healthcare) at a coupling density of $1 \mathrm{mM}$ in DMSO as described. ${ }^{4}$ The kinobeads generated were similar to the ones reported by Eberl et al. ${ }^{5}$

Pulldowns were performed in a 384 well plate (Greiner Bio-one, \#781280): $200 \mu \mathrm{L}$ of the lysate mix (5 mg. $\mathrm{mL}^{-1}$ protein concentration) was incubated with the respective inhibitor for $45 \mathrm{~min}$ at $4{ }^{\circ} \mathrm{C}$ over a range of concentrations followed by incubation with kinobeads in a 384 well filter plate (Merck Millipore, \#MZHVNOW50) for $1 \mathrm{~h}$ on an end-over-end rotator at $4{ }^{\circ} \mathrm{C}$. Beads were thoroughly washed in two steps with lysis buffer containing $0.4 \%$ and $0.2 \%$ IGEPAL CA-630 (octylphenoxypoly(ethyleneoxy)ethanol), respectively, and eluted with 50 $\mu \mathrm{L}$ of a $2 \times$ LDS sample buffer supplemented with $50 \mathrm{mM}$ DTT.

\section{MS sample preparation and LC-MS/MS analysis}

Eluates were alkylated with $200 \mathrm{mg} \cdot \mathrm{mL}^{-1}$ iodoacetamide for $30 \mathrm{~min}$ in the dark, separated on 4-12\% NuPAGE (Invitrogen) for approximately $2 \mathrm{~cm}$, and stained with colloidal Coomassie. Gel lanes were cut into three slices covering the entire separation range and subjected to in-gel digestion. Peptide samples were labelled with 10-plex TMT (TMT10, Thermo Fisher Scientific, Waltham, MA) reagents in $40 \mathrm{mM}$ triethylammonium bicarbonate (TEAB), pH 8.5. After quenching the reaction with hydroxylamine, labelled extracts were combined. To increase analytical depth, some samples were either fractionated into 9 fractions using 
reversed-phase chromatography at pH 12 (1 mm Xbridge column, Waters) or fractionated into 5 fractions using stage-tip based SCX fractionation. Samples were dried in vacuo and resuspended in $0.1 \%$ formic acid in water. Aliquots of the sample were injected into an Ultimate3000 RSLCnano system (Dionex, Sunnyvale, CA) coupled to a QExactive mass spectrometer (Thermo Fisher Scientific). Peptides were separated on custom $50 \mathrm{~cm} \times 100 \mu \mathrm{M}$ (ID) reversed-phase columns (Reprosil) at $40{ }^{\circ} \mathrm{C}$. Gradient elution was performed from $2 \%$ acetonitrile to $40 \%$ acetonitrile in $0.1 \%$ formic acid $2 \%$ DMSO over $4 \mathrm{~h}$ for unfractionated samples and $2 \mathrm{~h}$ per run for fractionated samples. Samples were online injected into Q-Exactive mass spectrometers operating with a data-dependent top 10 method. MS spectra were acquired by using 70,000 resolution and an ion target of 3E6. First mass was set at $375 \mathrm{~m} / \mathrm{z}$. Higher energy collisional dissociation (HCD) scans were performed with 35\% NCE at 35,000 resolution (at $\mathrm{m} / \mathrm{z} 200$ ), isolation width was set to 1Thompson and the ion target for MS2 was set to $2 \mathrm{E} 5$.

\section{Peptide and protein Identification and quantification}

Mascot 2.2 (Matrix Science) was used for protein identification using a $10 \mathrm{ppm}$ mass tolerance for peptide precursors and $20 \mathrm{mDa}$ (HCD) mass tolerance for fragment ions. A $2.5 \mathrm{mDa}$ mass tolerance was used for reporter ion extraction in HCD scans by an in-house-developed software. Carbamidomethylation of cysteine residues and TMT modification of lysine residues were set as fixed modifications and methionine oxidation, $N$-terminal acetylation of proteins and TMT modification of peptide N-termini were set as variable modifications. The search database consisted of a customized version of the IPI protein sequence database combined with a decoy version of this database created using a script supplied by Matrix Science.

Reporter ion intensities were read from raw data and multiplied with ion accumulation times (in $\mathrm{ms}$ ) so as to yield a measure proportional to the number of ions; this measure is referred to as ion area. Spectra matching to peptides were filtered according to the following criteria: mascot ion score $>15$, signal-to-background of the precursor ion $>4$, and signal-to-interference $>0.5$. Fold-changes were corrected for isotope purity as described and adjusted for interference caused by co-eluting nearly isobaric peaks as estimated by the signal-to-interference measure. Protein quantification was derived from individual spectra matching to distinct peptides by using a sum-based bootstrap algorithm. For dose-response inhibitor data dose-response curves were fitted using $\mathrm{R}$ and the drc package, as described. ${ }^{5}$ To compensate for bead-matrix induced depletion, $\mathrm{IC}_{50}$ values were corrected by an experimentally-derived depletion factor as described before. ${ }^{6}$ 


\section{Supplementary References}

[1] Henley, Z. A., Amour, A., Barton, N., Bantscheff, M., Bergamini, G., Bertrand, S. M., Convery, M., Down, K., Dumpelfeld, B., Edwards, C. D., Grandi, P., Gore, P. M., Keeling, S., Livia, S., Mallett, D., Maxwell, A., Price, M., Rau, C., Reinhard, F. B. M., Rowedder, J., Rowland, P., Taylor, J. A., Thomas, D. A., Hessel, E. M., and Hamblin, J. N. (2020) Optimization of Orally Bioavailable PI3Kdelta Inhibitors and Identification of Vps34 as a Key Selectivity Target, J. Med. Chem. 63, 638-655.

[2] Gray, A., Olsson, H., Batty, I. H., Priganica, L., and Peter Downes, C. (2003) Nonradioactive methods for the assay of phosphoinositide 3-kinases and phosphoinositide phosphatases and selective detection of signaling lipids in cell and tissue extracts, Anal. Biochem. 313, 234-245.

[3] Krippendorff, B. F., Neuhaus, R., Lienau, P., Reichel, A., and Huisinga, W. (2009) Mechanism-based inhibition: deriving $\mathrm{K}(\mathrm{I})$ and $\mathrm{k}$ (inact) directly from time-dependent $\mathrm{IC}(50)$ values, J. Biomol. Screen. 14, 913-923.

[4] Drewes, G., Kuester, B., Kruse, U., Hopf, C., Eberhard, D., Bantscheff, M., Reader, V., Raida, M., and Middlemiss, D. (2013) Process for the identification of novel enzyme interacting compounds. WO/2006/134056.

[5] Eberl, H. C., Werner, T., Reinhard, F. B., Lehmann, S., Thomson, D., Chen, P., Zhang, C., Rau, C., Muelbaier, M., Drewes, G., Drewry, D., and Bantscheff, M. (2019) Chemical proteomics reveals target selectivity of clinical Jak inhibitors in human primary cells, Sci. Rep. 9, 14159.

[6] Becher, I., Savitski, M. M., Savitski, M. F., Hopf, C., Bantscheff, M., and Drewes, G. (2013) Affinity profiling of the cellular kinome for the nucleotide cofactors ATP, ADP, and GTP, ACS Chem. Biol. 8, 599-607. 